\title{
Wabash River Coal Gasification Repowering Project: A DOE Assessment
}

January 2002

U.S. Department of Energy

National Energy Technology Laboratory

P.O. Box 880, 3610 Collins Ferry Road

Morgantown, WV 26507-0880

and

P.O. Box 10940, 626 Cochrans Mill Road

Pittsburgh, PA 15236-0940

website: $\underline{\text { www.netl.doe.gov }}$
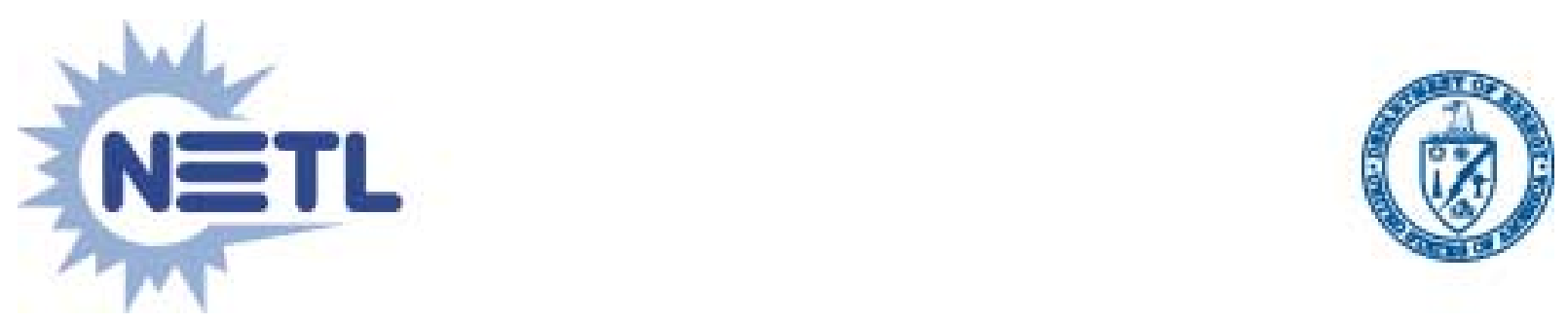


\section{Disclaimer}

This report was prepared as an account of work sponsored by an agency of the United States Government. Neither the United States Government nor any agency thereof, nor any of their employees, makes any warranty, express or implied, or assumes any legal liability or responsibility for the accuracy, completeness, or usefulness of any information, apparatus, product, or process disclosed, or represents that its use would not infringe privately owned rights. Reference therein to any specific commercial product, process, or service by trade name, trademark, manufacturer, or otherwise does not necessarily constitute or imply its endorsement, recommendation, or favoring by the United States Government or any agency thereof. The views and opinions of authors expressed therein do not necessarily state or reflect those of the United States Government or any agency thereof. 


\section{Contents}

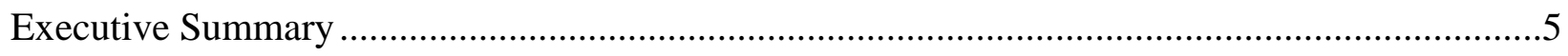

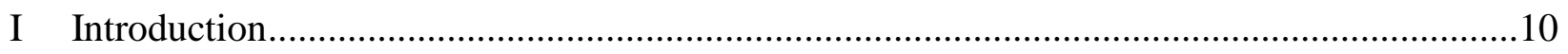

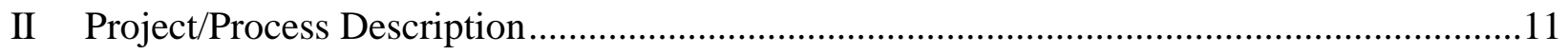

II.A Project Description .............................................................................. 11

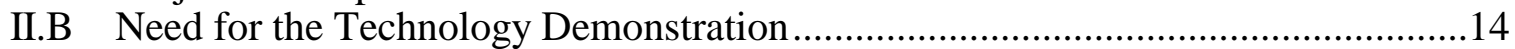

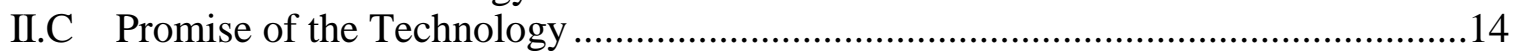

II.D Technology Description......................................................................... 14

II.D.1 Coal Handling............................................................................... 14

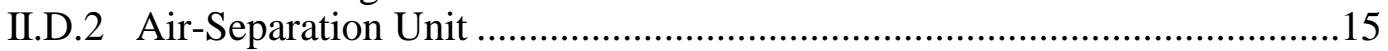

II.D.3 E-Gas TM Gasifier .......................................................................... 15

II.D.4 Syngas Conditioning/Cleanup .................................................. 17

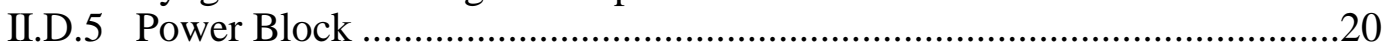

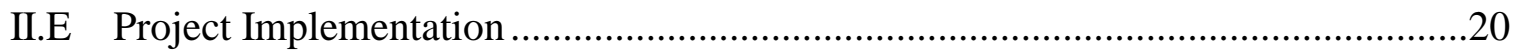

II.F Project Objective and Statement of Work .....................................................21

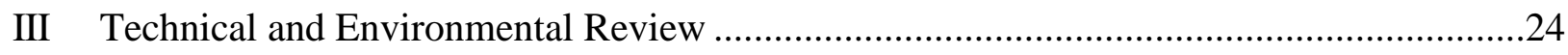

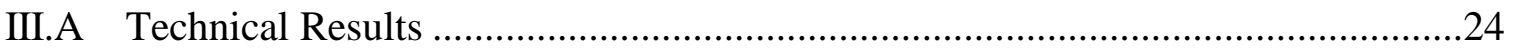

III.A.1 Air-Separation Unit ........................................................................25

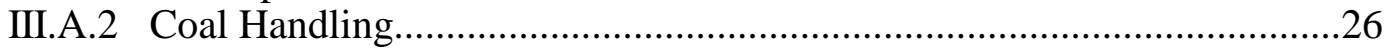

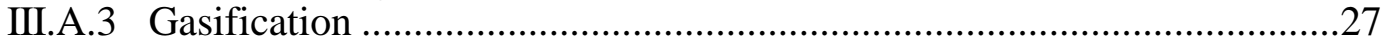

III.A.4 Syngas Cooling and Particulate Removal ............................................27

III.A.5 Chloride Scrubbing System and COS Hydrolysis .................................28

III.A.6 Low-Temperature Heat Recovery and Syngas Humidification................28

III.A.7 Acid-Gas Removal, Sulfur Recovery, and Sour-Water Stripping............29

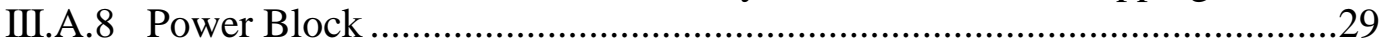

III.A.9 Operations Feeding Petroleum Coke.................................................29

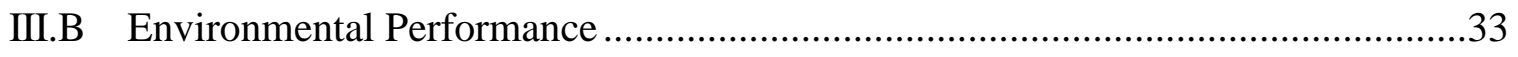

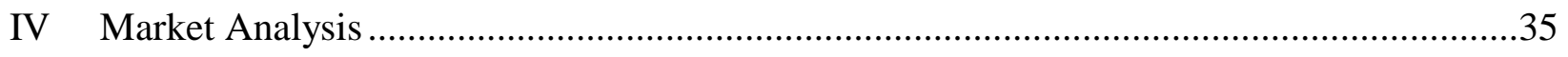

IV.A Market Size/Commercialization ............................................................... 35

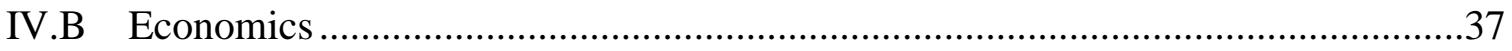

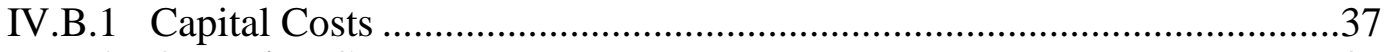

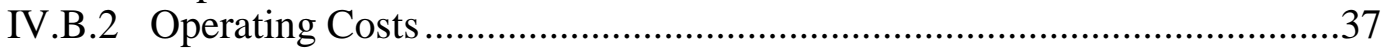

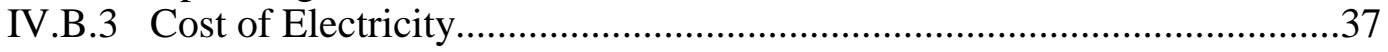

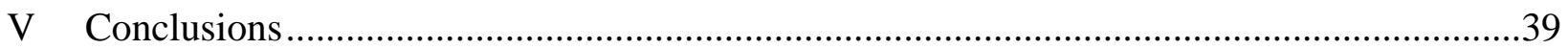




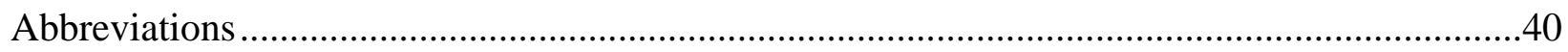

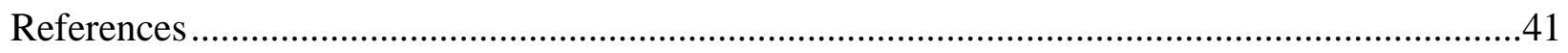

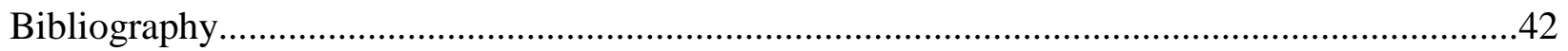

\section{List of Figures and Tables}

$\begin{array}{lll}\text { Figure } & \text { Page }\end{array}$

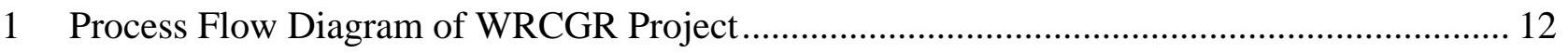

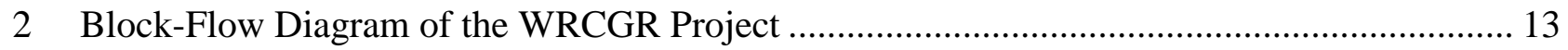

3 Simplified Block-Flow Diagram of Gasification Process....................................................... 15

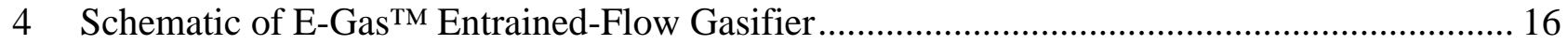

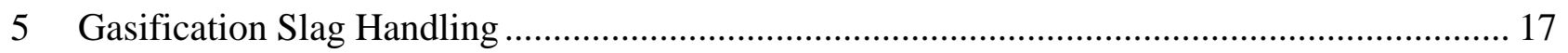

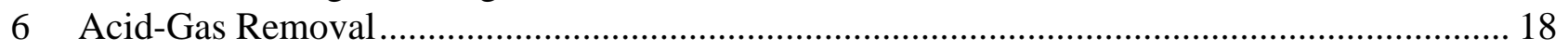

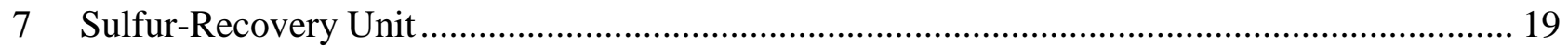

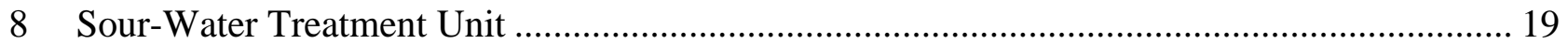

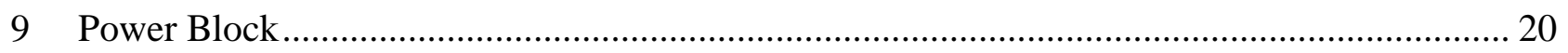

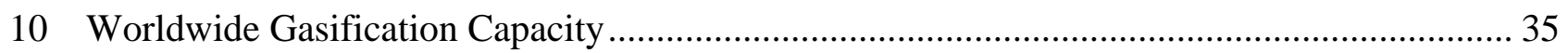

$\begin{array}{lll}\text { Table Page } & \text { Pas }\end{array}$

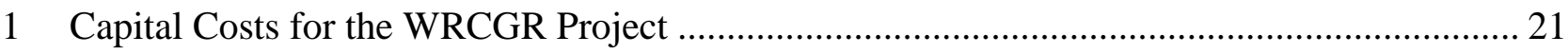

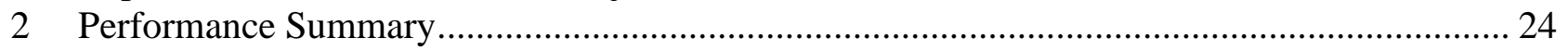

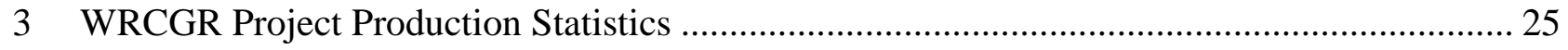

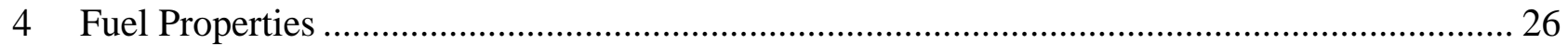

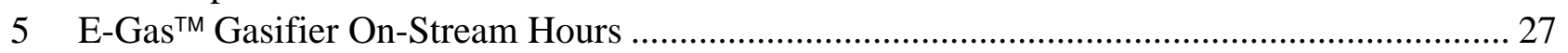

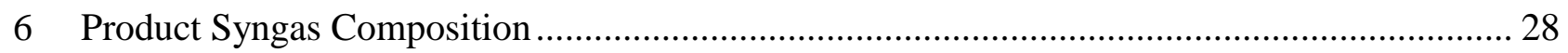

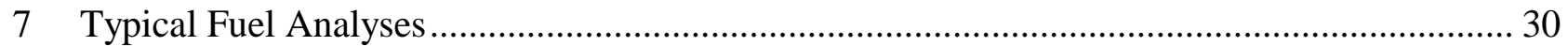

8 Thermal Performance Summary for Operations With Petroleum Coke …………….................. 31

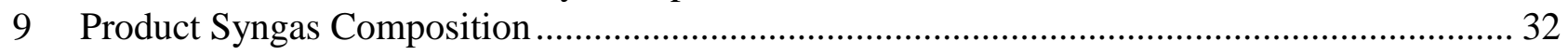

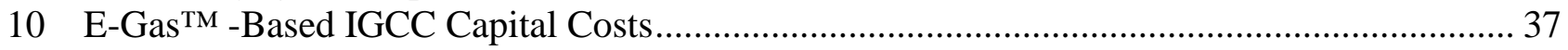

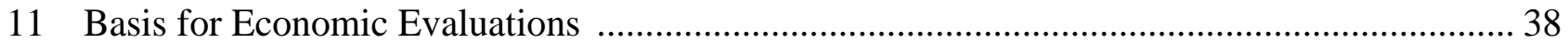

12 Economics* of Power Generation by an IGCC Unit Using E-Gas ${ }^{\mathrm{TM}}$ Technology ..................... 38 


\section{Executive Summary}

The U.S. Department of Energy (DOE) Clean Coal Technology (CCT) Program seeks to furnish the energy marketplace with more efficient and environmentally benign coal utilization technologies through demonstration projects. This document is a post-project assessment (PPA) of one of the demonstration projects selected in Round IV of the CCT Program, the Wabash River Coal Gasification Repowering (WRCGR) Project.

In July 1992, Destec Energy, Inc., and PSI Energy, Inc., entered into a cooperative agreement with DOE to demonstrate an application of the Destec gasifier to repower a pulverized coal-fired boiler using an integrated gasification combined-cycle (IGCC) system. The selected site for the project was PSI Energy's Wabash River power station in West Terre Haute, Indiana. Engineering services were provided by Sargent \& Lundy, Inc., and Dow Engineering Corp. The gasifier technology used in this CCT project has been renamed E-Gas ${ }^{\mathrm{TM}}$ Technology and is now owned by Global Energy, Inc. DOE provided 50 percent of the total project funding (for capital and operating costs during the demonstration period) of $\$ 438$ million.

The Wabash River power station consists of six units that had a nameplate generating capacity of 973 MWe prior to the WRCGR Project. The oldest of the units, Unit 1, with a nominal rating of $99 \mathrm{MWe}$, was repowered with the E-Gas ${ }^{\mathrm{TM}}$ Technology Gasifier and integrated with a new 192-MWe combustion turbine and a heat-recovery steam generator (HRSG). The main facilities retained were the steam turbine and its auxiliaries and the coal-handling equipment. The unit's rating increased to $262 \mathrm{MWe}$ (net) after repowering. In addition to demonstrating commercial operation of the E-Gas ${ }^{\mathrm{TM}}$ Gasifier in a utility electrical grid, the goal was to demonstrate a number of novel technical aspects of the project, including hot-particulate removal, hot-gas cooling by steam generation, syngas recycle, carbonyl sulfide hydrolysis, slag-fines recycle, fluegas moisturization, and sulfur plant tail-gas recycle.

IGCC technology promises greater than 40-percent efficiency, fuel flexibility, and very low pollutant emissions compared to pulverized-coal-fired plants. The electric utility industry has typically been reluctant to embrace IGCC for power generation because the equipment and operations are significantly different from what this industry is accustomed to using. The perception has been that, compared with conventional coal-based power production, IGCC systems are relatively complex, capital intensive, and present considerable risk for any utility planning such an installation. The commercial demonstration of the E-Gas TM Gasifier accomplished by this highly successful CCT project is helping dispel this perception and will facilitate the market penetration of IGCC technology.

In the E-Gas ${ }^{\mathrm{TM}}$ Technology process, coal is ground in a rod mill along with treated water and slag fines recycled from the gasifier. Slurry from the rod mill is stored in an agitated tank from which it is pumped to the gasifier. Ninety-five-percent oxygen from the air-separation unit (ASU) is compressed and fed to the gasifier along with the coal. 
The E-Gas ${ }^{\mathrm{TM}}$ Gasifier consists of two stages: a slagging first stage and an entrained-flow, non-slagging second stage. In the first stage, the fuel slurry is partially combusted with oxygen at nominal conditions of $2,600^{\circ} \mathrm{F}$ and 400 psia. Oxygen and slurry are fed into the first stage through two opposed mixing nozzles of proprietary design. The oxygen feed rate is controlled to maintain the gasification temperature above the ash fusion point. Fluxes may be added prior to the grinding stage to ensure that the slag is fluid at the first-stage temperature. Molten slag flows to the bottom of the gasifier, where it is quenched and then removed for sale or disposal. The gasifier is capable of handling a wide range of feedstocks.

In the E-Gas ${ }^{\mathrm{TM}}$ Gasifier, the slurry feed is almost completely converted to a syngas consisting primarily of hydrogen $\left(\mathrm{H}_{2}\right)$, carbon monoxide $(\mathrm{CO})$, carbon dioxide $\left(\mathrm{CO}_{2}\right)$, and water $\left(\mathrm{H}_{2} \mathrm{O}\right)$. Sulfur in the feed is converted to hydrogen sulfide $\left(\mathrm{H}_{2} \mathrm{~S}\right)$ with a small amount of carbonyl sulfide (COS). Nitrogen $\left(\mathrm{N}_{2}\right)$ in the coal is converted to ammonia $\left(\mathrm{NH}_{3}\right)$. In the second stage, additional slurry, (but no additional oxygen), is injected and undergoes devolatilization and pyrolysis. These endothermic reactions cool the syngas and increase its heating value because of the nature of the products produced.

The hot syngas is cooled from $1,900{ }^{\circ} \mathrm{F}$ to approximately $700{ }^{\circ} \mathrm{F}$ in the syngas cooler, which generates 1,600 -psia steam. The cooled syngas is sent to a filter vessel containing porous candle filters that remove in excess of 99.9 percent of the particulates. The particulate-free syngas is further cooled and then water scrubbed to remove chlorides and volatile trace metals, and piped to the COS hydrolysis unit, where COS is converted to $\mathrm{H}_{2} \mathrm{~S}$.

The syngas is then further cooled to $100{ }^{\circ} \mathrm{F}$ in the low-temperature heat-recovery unit. The cooled syngas is sent to the acid-gas removal system, where most of the $\mathrm{H}_{2} \mathrm{~S}$ and some $\mathrm{CO}_{2}$ are removed. The essentially sulfur-free syngas is then moisturized, superheated, and sent to the combustion turbine. Recovered acid gases are sent to the sulfur-recovery unit that produces 99.999-percent-pure sulfur. Greater than 98-percent sulfur recovery is achieved.

Preheated, moisturized syngas and compressed air are supplied to the combustion turbine that is coupled to an air compressor. Hot exhaust gas from the turbine is sent to the HRSG, which extracts heat from this gas to superheat the 1600-psia high-pressure (HP) steam from the syngas cooler and to generate additional steam. The superheated steam, two thirds of which has been generated in the syngas cooler, is directed to the throttle of the 1953 Westinghouse steam turbine. The steam-turbine system is composed of HP, intermediate-pressure (IP), and low-pressure (LP) power turbines and a generator. The IP steam from the HP turbine is reheated before being sent to the IP turbine. Steam from the LP turbine exhausts to the surface condenser.

Demonstration tests were conducted feeding bituminous coal from the No. 6 Seam at Peabody's Hawthorn Mine and other local mines and sponge coke from delayed cokers at two different refineries. Despite a successful startup, numerous operating problems impacted plant performance during the first year, resulting in only a 22-percent availability factor. Frequent failure of the ceramic filter elements accounted for nearly 40 percent of the downtime in the first year. A high chloride content in the syngas contributed to exchanger-tube failures in the lowtemperature heat-recovery area, COS-hydrolysis-unit catalyst degradation, and mechanical failure 
of the syngas recycle compressor in the first year, as well. Significant downtime was also required to remove ash deposits in the downstream pipe spool of the gasifier, and the hightemperature heat-recovery unit. The slurry mixers experienced several failures, and the power block contributed appreciable downtime.

The air-separation unit never met the full performance guarantees for simultaneous delivery of all product streams. Oxygen production from the unit was sufficient to meet gasifier demands, but nitrogen production did not meet the guarantees. Intermittent shutdowns of the main air compressor halted the gasification process several times during initial operations. A number of plant improvements were implemented to increase the availability of the air-separation unit.

Initially, the rod mill did not produce a fine enough grind, but this was corrected by adjusting the rod loading in the mill. Also, a number of areas of localized erosion and corrosion were identified throughout the slurry handling system. Where possible, hardened metal internal coatings were applied, while in some cases, metallurgy had to be changed to improve equipment life.

Natural-gas firing was used to heat the gasifier during startup and to keep it hot when problems occurred. Natural gas was not used to fire the gas turbine. During the period from 1996 through 1998, there was a continual improvement in operations, so that in 1998 only about 15 percent of total gasifier operating time was on natural gas. Problems associated with early gasifier operations included ash deposition in various locations and degradation of the brick lining. These problems were largely overcome by piping and operations changes and by using a different refractory brick to line the gasifier. Another problem area was the slurry mixers. Operational changes and installation of redesigned mixers improved this situation. Problems were also encountered with taphole plugging, which can occur when a coal whose ash viscosity varies is gasified without appropriate operating-temperature adjustments.

The particulate removal system was initially a significant source of problems, but a considerable increase in performance occurred when the ceramic filter elements were replaced with metallic elements. Design improvements to provide better flow distribution through the filter vessels were also helpful.

Syngas humidification was performed prior to the combustion turbine to control combustion temperature, reduce nitrogen oxides $\left(\mathrm{NO}_{\mathrm{X}}\right)$ formation, and improve efficiency. This system operated efficiently and provided consistent product gas moisture content of approximately 20 to 23 percent throughout the demonstration period. Syngas composition remained relatively constant, although coal composition varied. The acid-gas-removal system operated well for most of the demonstration period, with removal efficiency generally holding above 98 percent.

During the demonstration period, the power block produced 4,125 GWh of electric power. In general, the power block operated well until the first quarter of 1999, when the compressor failed. This failure was unrelated to gasifier operations. The unit was replaced by a new compressor from General Electric, which has operated successfully since its installation. 
Tests were conducted with petroleum coke to demonstrate the flexibility of IGCC technology. Petroleum coke has a low ash content and a high heating value, and its low fuel price can be used to offset the higher capital cost of an IGCC unit. The plant switched from coal to 100-percent as-received petroleum coke from November 17 through November 27, 1997, without interrupting operations. Slag from an earlier coal test, with known ash flow characteristics, was added to the coke as a fluxing agent. Trace metals in the petroleum coke, mainly vanadium and nickel, were encapsulated in an inert slag that was non-leachable and safe for disposal or by-product use.

Steady operation at full load was achieved with 100-percent petroleum coke, while meeting all environmental emissions criteria. Operation was maintained at approximately 90 percent of gasifier capacity for most of the test to match the combustion-turbine fuel requirement. Plant efficiency at 40.2 percent (high heating value (HHV)) was slightly improved compared to coal operation. The composition of the cleaned syngas produced from coke was very similar to that produced with bituminous coal. The overall conclusion from the petroleum coke test is that operations with petroleum coke are not significantly different from operations with coal and that the equipment and systems at Wabash River are adequate for this operation without modification.

Sulfur dioxide $\left(\mathrm{SO}_{2}\right)$ emissions and $\mathrm{NO}_{\mathrm{X}}$ emissions were well below Clean Air Act requirements. Plant by-products were pure sulfur and non-hazardous slag, both with active commercial markets. Some environmental problems were encountered with water quality caused by the condensation of arsenic, selenium, and cyanide from the syngas vapor into the process wastewater. Investigations are underway to mitigate this problem by identifying the most cost-effective, currently available technologies. Despite problems during the first 2 years of operation, plant performance compared favorably with the design values.

Two potential markets exist for the E-Gas ${ }^{\mathrm{TM}}$ Technology: new gasification projects and retrofits of existing conventional coal-fired power-generating stations striving to meet tightening environmental standards. By 2004, projected world gasification projects should amount to $30 \mathrm{GW}$, of which approximately 54 percent will be based on coal or petroleum coke. The EGas $^{\mathrm{TM}}$ Technology, because of its successful demonstration in this project, could capture a significant fraction of this market. The estimated capital cost (in year 2000 dollars) of a 262MWe power plant, based on E-Gas ${ }^{\mathrm{TM}}$ Technology and built on a Greenfield site, is $\$ 1,275 / \mathrm{kW}$ for a coal-fired unit and $\$ 1,150 / \mathrm{kW}$ for a petroleum coke-fired unit. These costs include the gasifier, pollution control, ASU, and power block. The higher heating value and lower ash content of petroleum coke results in lower capital costs with this fuel. Based on a heat rate of $8,250 \mathrm{Btu} / \mathrm{kWh}(\mathrm{HHV})$, the levelized cost of power is estimated to be $42.0 \mathrm{mills} / \mathrm{kWh}$ (constant dollars) with coal and $29.3 \mathrm{mills} / \mathrm{kWh}$ with petroleum coke.

The WRCGR Project demonstrated the successful operation of the E-Gas ${ }^{\mathrm{TM}}$ Technology at commercial scale. For extended periods, the syngas produced was burned in a combustion turbine to produce electric power. When integrated with well-designed auxiliary units, the EGas ${ }^{\mathrm{TM}}$ Gasifier emits very low levels of $\mathrm{NO}_{\mathrm{X}}, \mathrm{SO}_{2}$, and particulates, and produces high-purity elemental sulfur for sale as well as an inert vitreous slag for sale or disposal in a regular landfill. Production of elemental sulfur eliminates the problem of disposing of large quantities of scrubber sludge. 
The E-Gas ${ }^{\mathrm{TM}}$ Gasifier operated successfully feeding both bituminous coal and petroleum coke, thus demonstrating its ability to handle a wide range of feeds. The potential exists to use a variety of opportunity fuels, such as municipal solid waste (MSW), refuse derived fuel (RDF), sewage sludge, waste tires, etc., either alone or, more probably, cofired with coal. All the technical objectives were achieved.

The success of this CCT project should not only advance the commercialization of the E-Gas ${ }^{\mathrm{TM}}$ Technology, but also increase acceptance of IGCC systems in general. Future replication of the E-Gas ${ }^{\text {TM }}$ Gasifier will furnish the marketplace with an efficient and environmentally benign technology capable of meeting today's strict environmental standards. 


\section{Introduction}

The goal of the U.S. Department of Energy (DOE) Clean Coal Technology Program (CCT) is to furnish the energy marketplace with a number of advanced, more efficient, and environmentally responsible coal utilization technologies through demonstration projects. These projects seek to establish the commercial feasibility of the most promising advanced coal technologies that have developed beyond the proof-of-concept stage.

This document serves as a DOE post-project assessment (PPA) of a project selected in CCT Round IV, the Wabash River Coal Gasification Repowering (WRCGR) Project, as described in a Report to Congress (U.S. Department of Energy 1992). Repowering consists of replacing an existing coal-fired boiler with one or more clean coal technologies to achieve significantly improved environmental performance. The desire to demonstrate utility repowering with a twostage, pressurized, oxygen-blown, entrained-flow, integrated gasification combined-cycle (IGCC) system prompted Destec Energy, Inc., and PSI Energy, Inc., to form a joint venture and submit a proposal for this project. In July 1992, the Wabash River Coal Gasification Repowering Project Joint Venture (WRCGRPJV, the Participant) entered into a cooperative agreement with DOE to conduct this project. The project was sited at PSI Energy's Wabash River Generating Station, located in West Terre Haute, Indiana. The purpose of this CCT project was to demonstrate IGCC repowering using a Destec gasifier and to assess long-term reliability, availability, and maintainability of the system at a fully commercial scale. DOE provided 50 percent of the total project funding (for capital and operating costs during the demonstration period) of $\$ 438$ million.

Construction for the demonstration project was started in July 1993. Pre-operational tests were initiated in August 1995, and construction was completed in November 1995. Commercial operation began in November 1995, and the demonstration period was completed in December 1999. The independent evaluation contained herein is based primarily on information provided in Wabash's Final Report (Dowd 2000), as well as other references and bibliographic sources.

Destec was acquired by NGC Corp. in 1997. NGC changed its name to Dynegy in 1998. In December 1999, Global Energy, Inc. purchased Dynegy's gasification assets, including the Wabash River Syngas Facility and the Destec gasification technology, and renamed the process the E-Gas ${ }^{\mathrm{TM}}$ Technology. To be consistent with the current status, the gasifier will be referred to as the E-Gas ${ }^{\mathrm{TM}}$ Gasifier throughout the rest of this PPA. 


\section{Project/Process Description}

\section{II.A Project Description}

The Wabash River Station consists of six units that had a total nameplate generating capacity of 973 MWe before the CCT repowering project on Unit 1, the oldest of the units. The E-Gas ${ }^{\mathrm{TM}}$ Technology Gasifier is integrated with a new 192-MWe General Electric MS-7001F (Frame 7FA) single-shaft combustion turbine and a heat-recovery steam generator (HRSG) for repowering a Westinghouse steam-turbine generator (first operated in 1953 with a nominal rating of $99 \mathrm{MWe}$ ). A process flow diagram of the WRCGR Project is shown in Figure 1. The repowered Unit 1 has a generating capacity of $262 \mathrm{MWe}$ (net).

The new and existing coal handling facilities, interconnections, and other auxiliaries that make up the Wabash IGCC repowering project (Figure 2) include:

- Coal handling and feed system (coal receiving, stockpiling, and slurry preparation).

- Air-separation unit (ASU).

- E-Gas ${ }^{\mathrm{TM}}$ oxygen-blown, entrained-flow, two-stage gasifier, capable of operating on a variety of feedstocks, including high-sulfur bituminous coal and petroleum coke.

- Syngas cleanup system to remove particulates, ammonia, chlorides, and sulfur compounds.

- Sulfur-recovery unit (SRU), which produces high-purity elemental sulfur.

- Combustion turbine/generator system that burns the syngas and generates electric power.

- HRSG that recovers heat from the combustion turbine exhaust and generates steam that is then sent to a steam turbine/generator.

The WRCGR Project is designed to use a range of local coals with a maximum sulfur content of 5.9 percent (dry basis) and a higher heating value of 13,500 Btu/lb (moisture- and ash-free). The coal selected for initial operation was a high-sulfur Midwestern bituminous from the No. 6 seam at Peabody's Hawthorn Mine in Indiana. Coal for the project is stored apart from the compliance coal burned in the other units. Alternative feedstocks, including petroleum coke and blends of coal and coke, were tested during the demonstration period.

In addition to the original JV members, Sargent \& Lundy provided engineering services to PSI, and Dow Engineering \& Construction Services (DE\&CS) provided engineering services to Destec. 


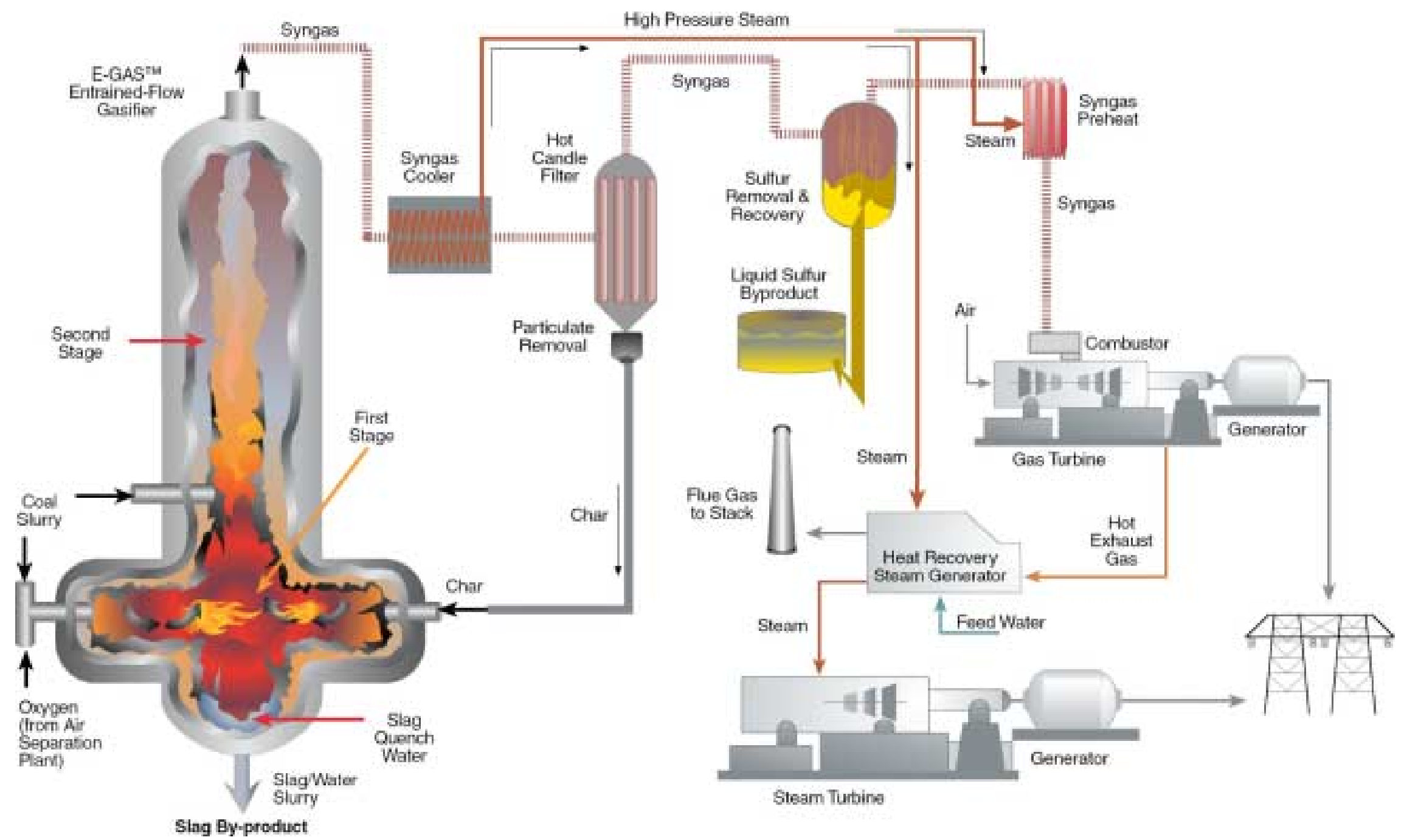

Figure 1. Process Flow Diagram of WRCGR Project 


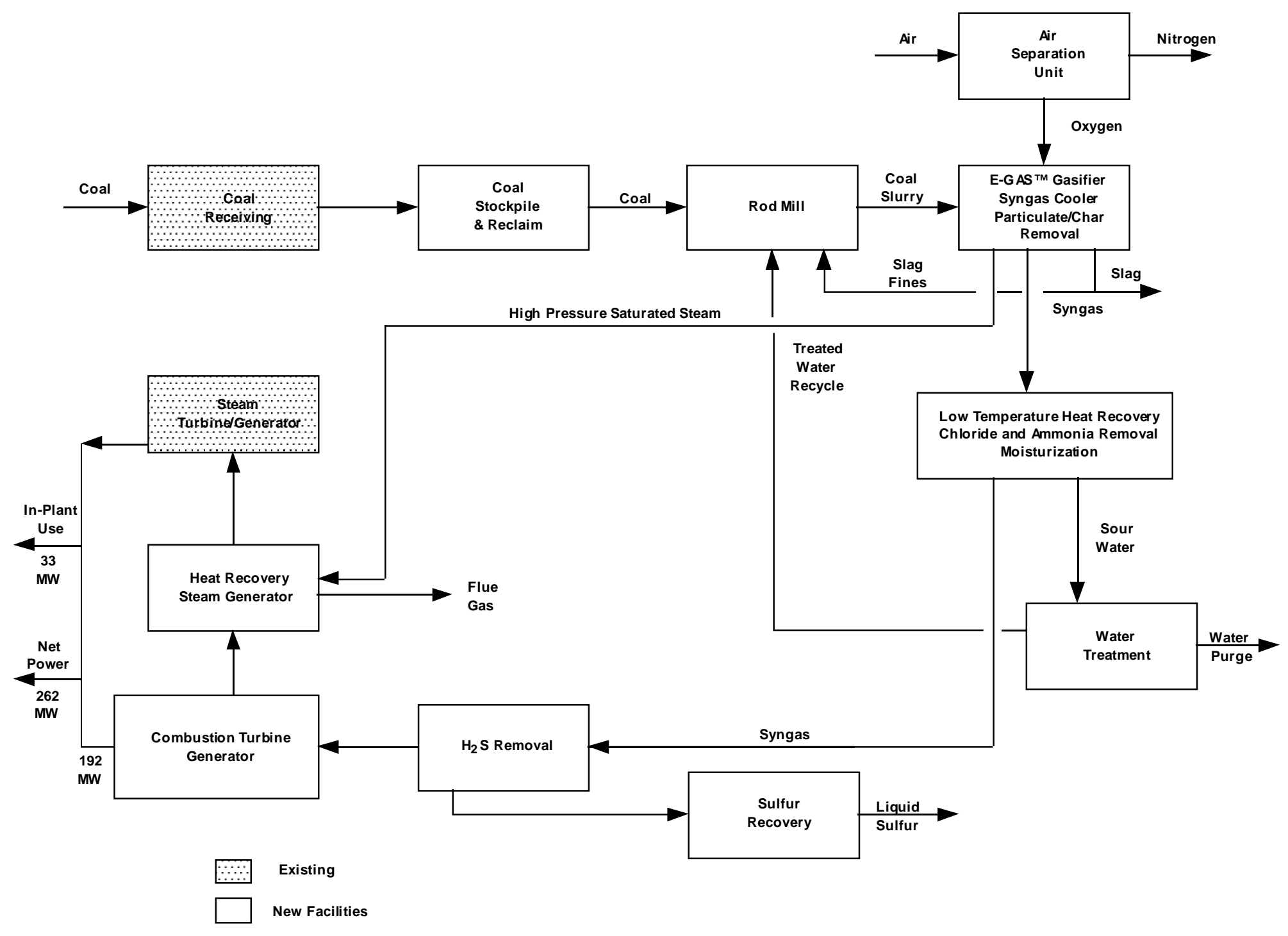

Figure 2. Block-Flow Diagram of the WRCGR Project 


\section{II.B Need for the Technology Demonstration}

One of the objectives of the CCT Program is to advance the commercialization of coalgasification technology. The electric-utility industry has been reluctant to utilize coal gasifiers, because these units are significantly different from the kinds of plants this industry typically operates. IGCC systems offer the possibility of improved efficiency and reduced emissions from coal-based power production; however, at the time of the solicitation in 1991, these systems were perceived as complex, capital intensive, high-risk installations. In order for this new technology to penetrate the marketplace, it would have to be successfully demonstrated at a commercial, or near-commercial scale. Thus, the demonstration provided by this CCT project is critical to the further commercialization of the E-Gas ${ }^{\mathrm{TM}}$ Technology and the acceptance of IGCC technology in general.

\section{II.C Promise of the Technology}

The promise of this technology is to provide a technique for power production that has greater than 40-percent efficiency, fuel-flexibility, and very low pollutant emissions. Gasification of the fuel before combustion permits the use of combined-cycle power generation with its inherently higher efficiency. Furthermore, the gasifier can accept many different materials as feedstock, including coal, low-value materials like petroleum coke, or materials that may have a negative value, like sewage sludge.

Finally, the technology inherently has low emissions compared to pulverized coal (PC)-fired plants. During the gasification process, sulfur in the feed is converted to hydrogen sulfide $\left(\mathrm{H}_{2} \mathrm{~S}\right)$, and nitrogen in the feed is converted to ammonia $\left(\mathrm{NH}_{3}\right)$. Both substances are easily scrubbed from the product syngas. The $\mathrm{H}_{2} \mathrm{~S}$ is converted to high-purity elemental sulfur, a bulk commodity that is readily marketable. Because all the nitrogen in the fuel is converted to $\mathrm{NH}_{3}$, which is removed before the syngas is burned, no fuel nitrogen oxides $\left(\mathrm{NO}_{\mathrm{X}}\right)$ are produced (fuel $\mathrm{NO}_{\mathrm{X}}$ is a major source of $\mathrm{NO}_{\mathrm{X}}$ emissions from PC-fired boilers); and, by controlling the temperature in the combustion turbine, thermal $\mathrm{NO}_{\mathrm{X}}$ is reduced.

\section{II.D Technology Description}

\section{II.D.1 Coal Handling}

Coal, with a 2-in. maximum top size, is delivered by rail and placed in a storage pile. The coal is transferred from the storage pile to a conveyor. The coal goes to a hopper that empties onto a weigh belt feeder, which feeds a rod mill. In the rod mill, the coal is mixed with treated water and slag fines recycled from the gasifier. A fluxing agent is sometimes added at the coal mine before shipment to adjust the fusion temperature of the coal ash. Slurry from the rod mill is stored in an agitated tank, with sufficient capacity to maintain gasifier operation during routine 
maintenance of the weigh belt feeder and rod mill. First- and second-stage gasifier feed pumps supply slurry to the gasifier.

\section{II.D.2 Air-Separation Unit}

The ASU provides the oxygen required by the gasifier. The ASU consists of a three-stage centrifugal air compressor (including interstage coolers), an air chiller, a pressure-swing adsorption system, air-separation cold box, a three-stage, radial turbo oxygen compressor, and a nitrogen handling and storage system. Compressed air is cooled to approximately $40{ }^{\circ} \mathrm{F}$ and sent to molecular sieve adsorbers that remove moisture, carbon dioxide $\left(\mathrm{CO}_{2}\right)$, and contaminants. The dry, $\mathrm{CO}_{2}$-free air is sent to the cryogenic distillation system (cold box) to separate the liquid air into its component elements and concentrate the oxygen. The resulting oxygen with 95-percent purity is compressed and fed to the gasifier. A small portion of the nitrogen produced by the ASU is high purity (99.9 percent) and is used for purging and inert blanketing. The rest of the nitrogen, containing 1- to 2-percent oxygen, is used for air chilling and then vented to the atmosphere.

\section{II.D.3 E-Gas ${ }^{\mathrm{TM}}$ Gasifier}

The design of the project gasifier was based on Destec's Louisiana Gasification Technology, Inc., (LGTI) gasifier, which was similar in size and operating characteristics. The LGTI gasifier was operated for more than 34,000 hours from April 1987 through November 1995. Experience gained in that project provided significant input to the design of the Wabash River coal gasification facility and eliminated much of the risk associated with scale-up.

Figure 3 is a simplified block flow diagram of the entire gasification area. The E-Gas ${ }^{\mathrm{TM}}$ Gasifier (Figure 4) consists of two stages: a slagging first stage; and an entrained-flow, non-slagging second stage. The first stage is a horizontal, refractory-lined vessel in which carbonaceous fuel is partially combusted with oxygen at an elevated temperature and pressure $\left(2600^{\circ} \mathrm{F}, 400 \mathrm{psia}\right)$.

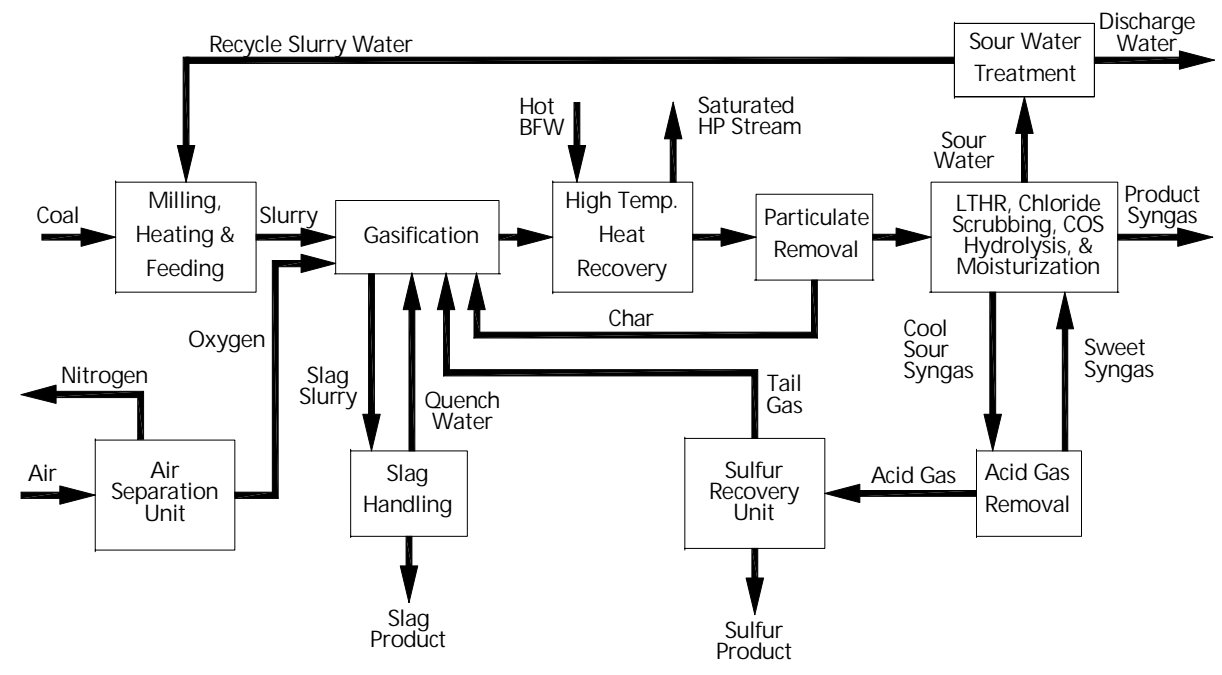

Figure 3. Simplified Block-Flow Diagram of Gasification Process 
The gasifier is initially heated with natural gas and then switched to coal slurry. Oxygen and preheated slurry are fed to two opposed, proprietary-design mixing nozzles, one on each end of the horizontal section of the gasifier. The oxygen feed rate is controlled to maintain the gasification temperature above the ash fusion point. Under gasifier conditions, the feed is almost completely converted to a gas consisting primarily of hydrogen $\left(\mathrm{H}_{2}\right)$, carbon monoxide $(\mathrm{CO})$, carbon dioxide $\left(\mathrm{CO}_{2}\right)$, and water $\left(\mathrm{H}_{2} \mathrm{O}\right)$.

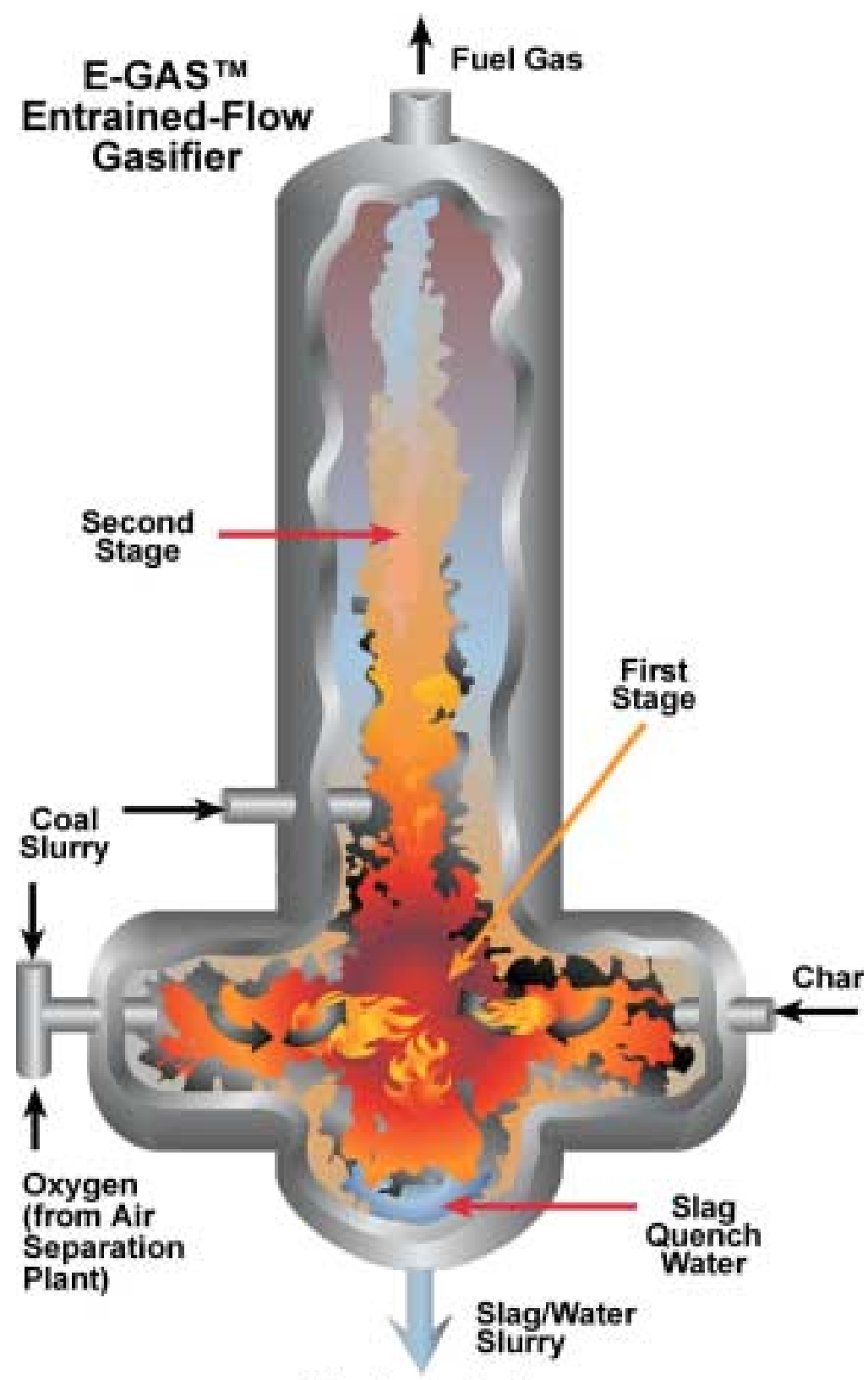

Slag By-product

Figure 4. Schematic of E-Gas ${ }^{\mathrm{TM}}$ Entrained-Flow Gasifier 
Coal-ash and any added flux form a molten slag that flows continuously through a tap hole in the floor of the horizontal section into a quench water bath. The solidified slag that exits from the bottom of the quench section is crushed and flows through a continuous removal system as a slag/water slurry (Figure 5). The slurry flows to a dewatering bin, where the bulk of the slag settles out, while the overflow goes to a settler for removal of the remaining fines. The clarified water is cooled and returned to the gasifier quench section. To improve carbon utilization, the slurry of fine particles from the bottom of the settler is recycled to the slurry preparation area. The dewatered slag is loaded onto trucks or rail cars for sale or disposal.

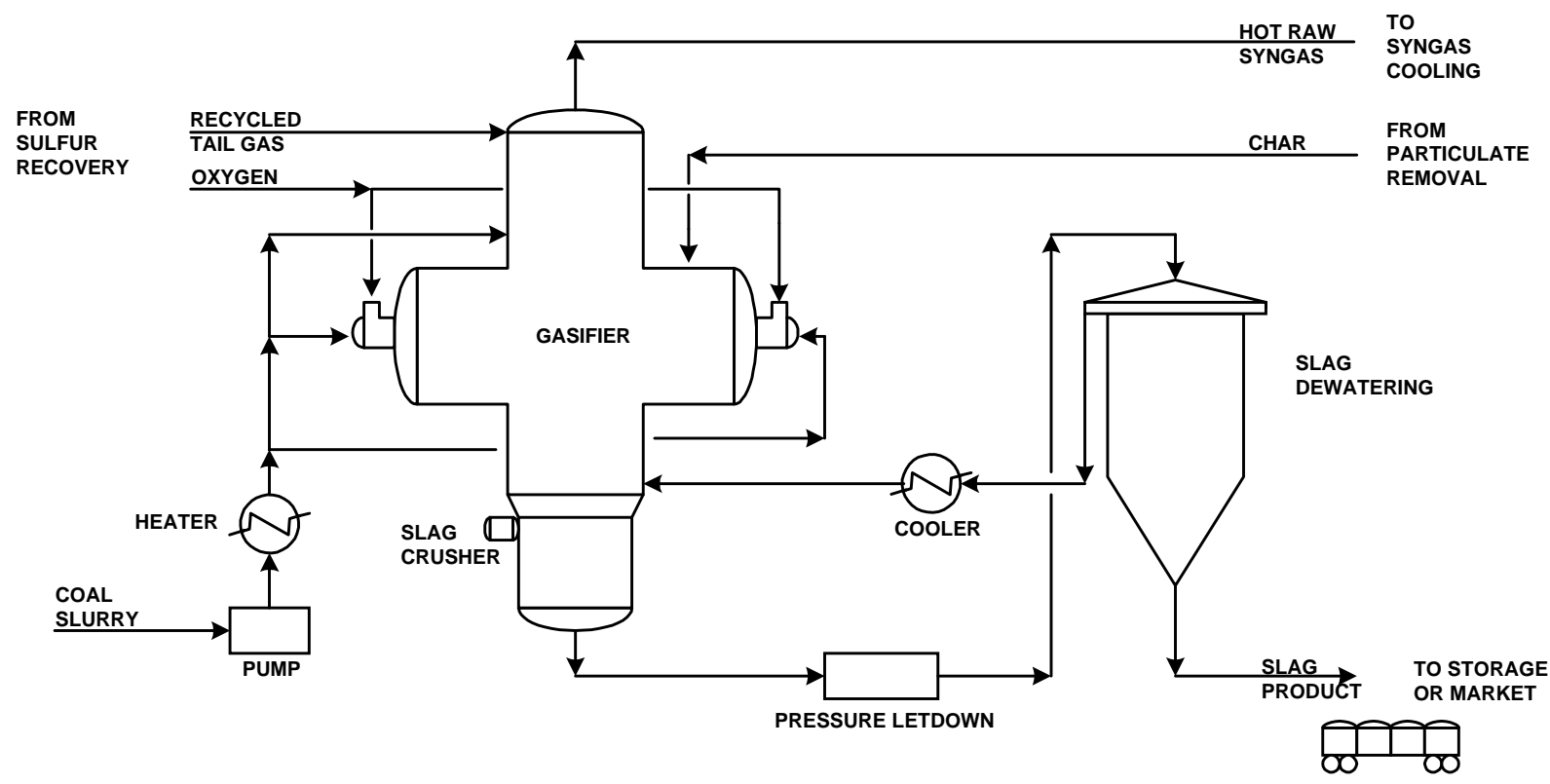

Figure 5. Gasification Slag Handling

Raw syngas from the first stage of the gasifier flows up into a vertical, refractory-lined, second-stage vessel, where additional slurry, but no additional oxygen, is injected. The injected fuel undergoes devolatilization and pyrolysis that both cools the syngas (because these reactions are endothermic) and increases its heating value (because of the nature of the products produced). In addition, water reacts with some of the carbon to produce $\mathrm{CO}$ and $\mathrm{H}_{2}$. Unreacted char is carried overhead with the syngas that leaves the gasifier at $1,900{ }^{\circ} \mathrm{F}$.

\section{II.D.4 Syngas Conditioning/Cleanup}

The hot syngas exiting the gasifier is cooled from a nominal $1,900{ }^{\circ} \mathrm{F}$ to approximately $700{ }^{\circ} \mathrm{F}$ in the syngas cooler, a vertical firetube heat-recovery boiler system with the hot syngas on the tube side. The syngas cooler generates 1,600 psia steam (compared to 600 psia steam generation in Destec's LGTI facility). The cooled syngas is sent to the particulate-removal system containing a large number of porous candle filter elements that remove more than 99.9 percent of the particulates. The filter elements are periodically back-pulsed with high-pressure syngas to 
remove built-up cake. Char cake dislodged from the filter elements falls to the bottom of the vessel and is pneumatically transferred to the first stage of the gasifier by high-pressure syngas.

The particulate free syngas is further cooled and then water scrubbed with sour water (i.e., sulfur-containing water condensed from the syngas) to remove chlorides and volatile trace metals. The scrubbed syngas goes to the COS hydrolysis unit, where COS is converted to $\mathrm{H}_{2} \mathrm{~S}$. The syngas is then cooled to $100^{\circ} \mathrm{F}$ before being sent to the acid-gas removal (AGR) system. During cooling, water condenses and dissolves most of the $\mathrm{NH}_{3}$, along with some $\mathrm{CO}_{2}$ and $\mathrm{H}_{2} \mathrm{~S}$. This water is sent to the sour-water treatment unit.

The AGR system (Figure 6) contacts the sour syngas with methyldiethanolamine (MDEA) in an absorption column to remove most of the $\mathrm{H}_{2} \mathrm{~S}$ and some of the $\mathrm{CO}_{2}$. The essentially sulfur-free syngas is moisturized and then superheated and sent to the combustion turbine. The MDEA is regenerated in an $\mathrm{H}_{2} \mathrm{~S}$ stripper column, with the concentrated $\mathrm{H}_{2} \mathrm{~S}$ stream being sent to the SRU.

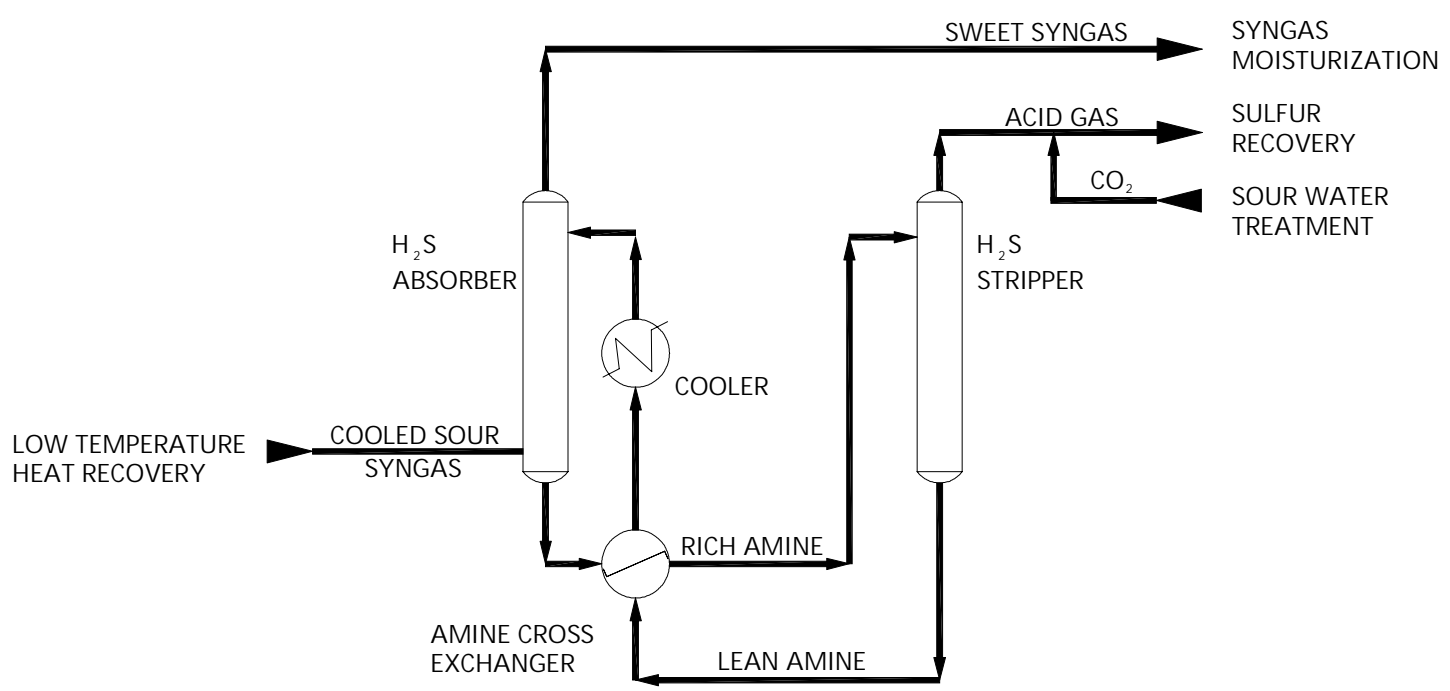

Figure 6. Acid-Gas Removal

In the SRU (Figure 7), the acid gas from the stripper and the $\mathrm{H}_{2} \mathrm{~S} / \mathrm{CO}_{2}$ stripped from the sour water are mixed with oxygen and fed to a furnace where one third of the $\mathrm{H}_{2} \mathrm{~S}$ is oxidized to $\mathrm{SO}_{2}$. A waste-heat boiler recovers heat before a condenser cools the gas to recover the first increment of sulfur. Offgas from the condenser passes through a series of heaters, catalytic reactors, and sulfur condensers, which produce 99.999-percent pure sulfur for sale. Offgas from the SRU, consisting mainly of nitrogen $\left(\mathrm{N}_{2}\right), \mathrm{CO}_{2}$, and $\mathrm{H}_{2} \mathrm{O}$, with traces of sulfur compounds, is catalytically hydrogenated to convert all the sulfur species to $\mathrm{H}_{2} \mathrm{~S}$. The gas, cooled to condense most of the water, is then recycled to the E-Gas ${ }^{\mathrm{TM}}$ Gasifier. This processing scheme allows greater than 98- percent sulfur recovery overall. 
Dissolved gases are stripped from the sour water in a two-step process (Figure 8). First, $\mathrm{CO}_{2}$ and most of the $\mathrm{H}_{2} \mathrm{~S}$ are removed in a steam stripper. The offgas from the steam stripper is sent to the SRU. The water from the bottom of the steam stripper is split into two streams. Most of the water is recycled to slurry preparation with any water not needed for slurry preparation being sent to an ammonia stripper. The stripped ammonia is dissolved in the water being sent to slurry preparation, and the treated water is stored for reuse or discharge. Reuse of water within the plant minimizes water consumption and discharge of pollutants.

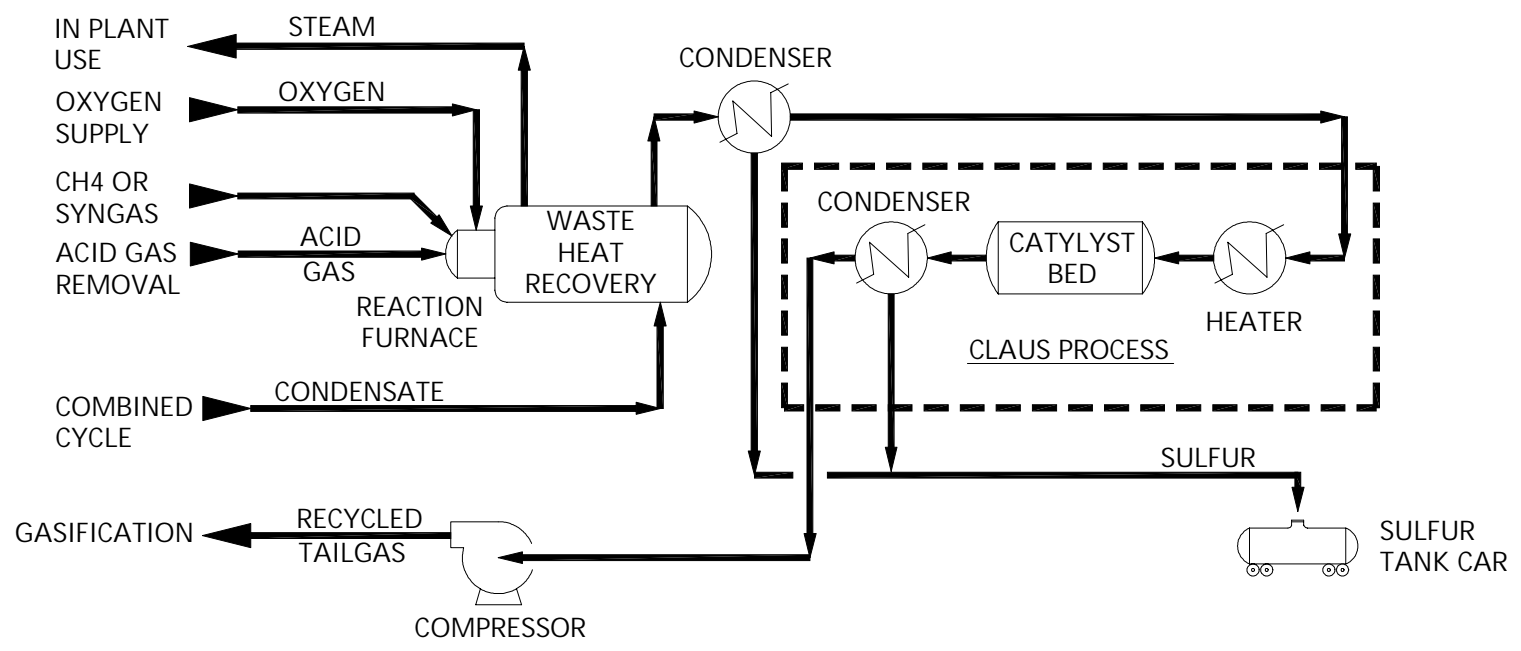

Figure 7. Sulfur-Recovery Unit

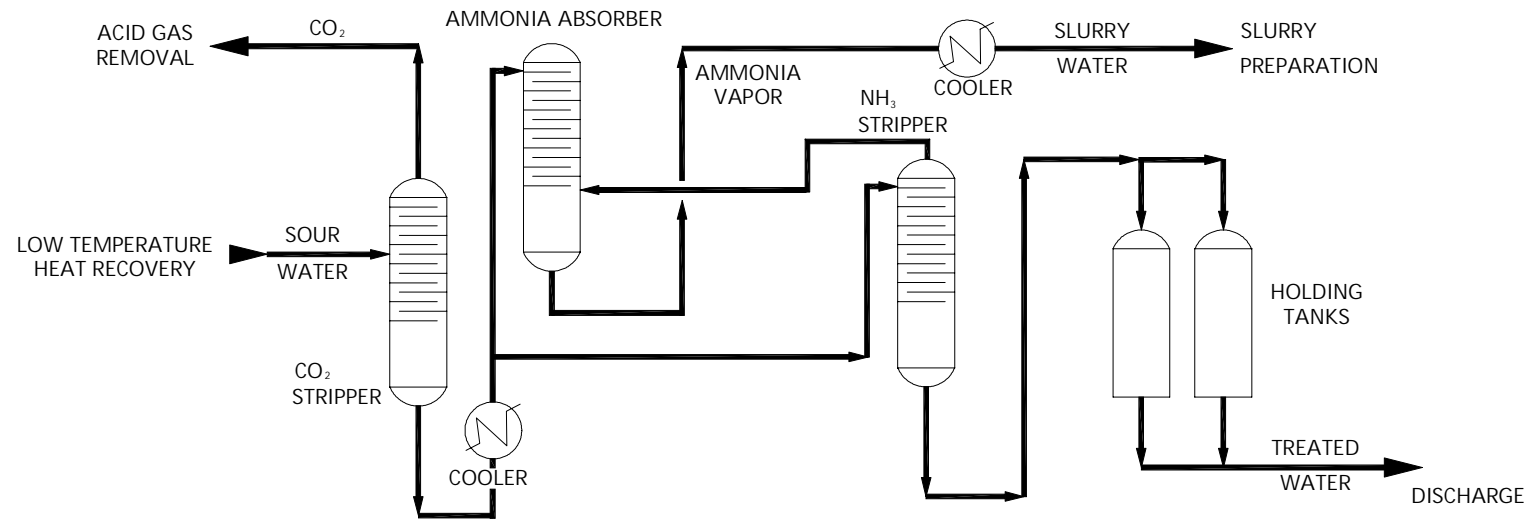

Figure 8. Sour-Water Treatment Unit 


\section{II.D.5 Power Block}

Preheated, moisturized syngas and compressed air are supplied to the combustor of the combustion turbine. The hot gas leaving the combustor flows to the turbine, which drives a generator and air compressor. Hot exhaust gas from the turbine is sent to the HRSG. The HRSG superheats the 1,600-psia HP steam produced by the gasifier, reheats the IP steam, and generates HP steam, as shown in Figure 9. About two-thirds of the steam-turbine throttle steam is actually generated in the gasification-facility syngas cooler.

The steam-turbine system is composed of HP, IP, and low-pressure (LP) power turbines and a generator. The IP steam from the HP turbine is reheated before being sent to the IP turbine. Steam from the LP turbine exhausts to the surface condenser. Process heat from the gasifier is used to preheat the condensate from the steam turbine condenser before it is returned to the HRSG.

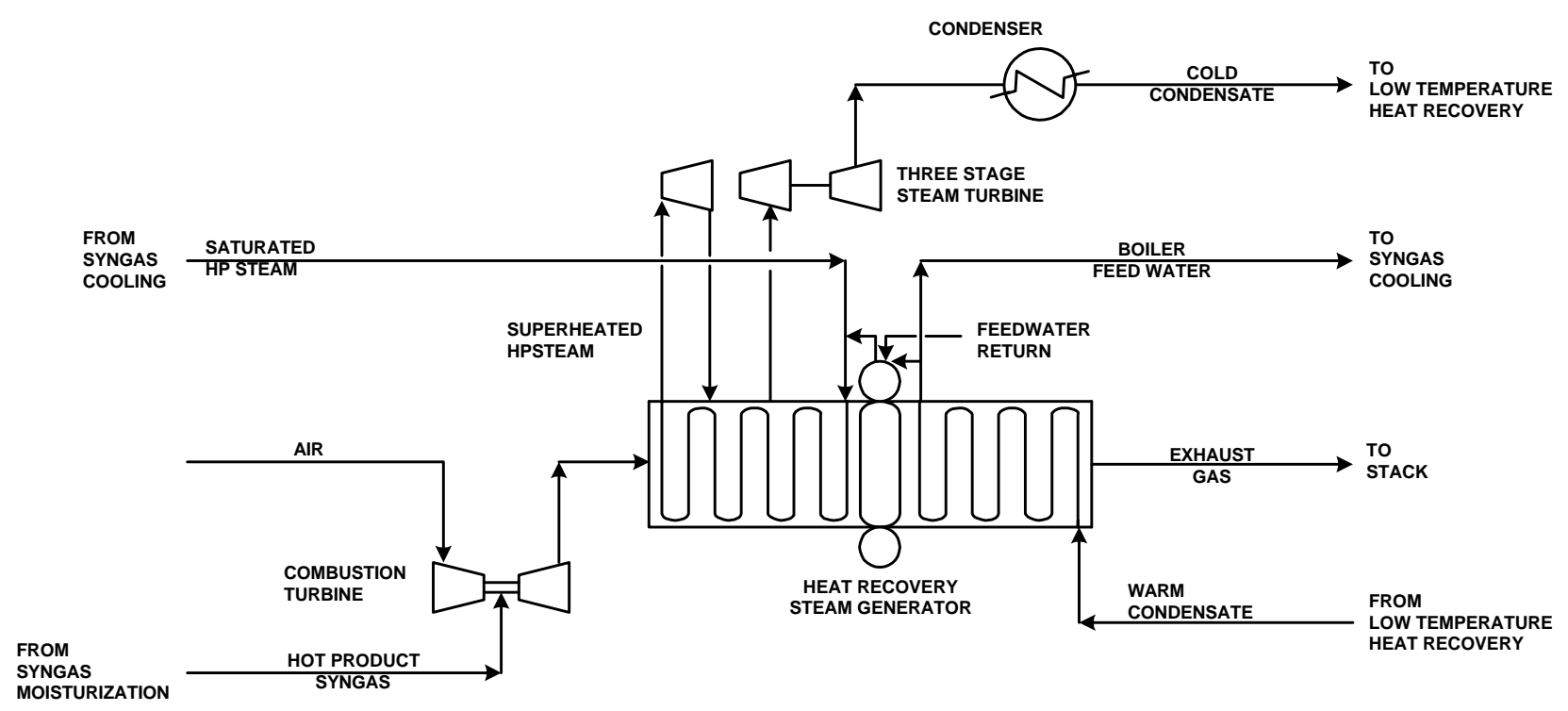

Figure 9. Power Block

\section{II.E Project Implementation}

Destec acted as the general contractor for the gasifier and related facilities. PSI acted as general contractor for the power block. Detailed design engineering and procurement was subcontracted to DE\&CS for the gasifier and to Sargent \& Lundy for the power block. The ASU was subcontracted to Liquid Air Engineering Corporation (Air Liquide) as a turnkey contract. Capital costs (1994 dollars) for the project are given in Table 1. 
Table 1. Capital Costs for the WRCGR Project

\begin{tabular}{|l|c|}
\hline Cost Element & \$ Million \\
\hline \multicolumn{2}{|l|}{ Syngas Facility } \\
\hline Engineering and Project Management & 27.3 \\
\hline Equipment Procurement & 84.5 \\
\hline Construction & 106.1 \\
\hline Construction Management & 8.1 \\
\hline ASU & 32.8 \\
\hline Preoperations Management & 21.7 \\
\hline Power Block & 136.1 \\
\hline Total & 416.6 \\
\hline
\end{tabular}

These costs include conceptual, process, and detailed engineering; environmental permitting; equipment procurement; project management; construction management; construction and start-up; and hiring and training operating personnel. Not included are fuel supply, interest paid during construction, financing fees, and license fees. Based on a design capacity of $262 \mathrm{MWe}$ (net), installed cost was $\$ 1,590 / \mathrm{kW}$. The project was designed to achieve very low $\mathrm{SO}_{\mathrm{X}}$ emissions; this added approximately $\$ 100 / \mathrm{kW}$ to the capital cost. Other factors that increased costs were inclement weather, equipment delivery problems, subcontract problems, and start-up problems. An additional $\$ 14$ million was spent during the first 2 years of operation to improve plant performance. The project included a spare gasifier so that operations could continue during the periodic rebricking of one of the gasifier vessels.

\section{II.F Project Objective and Statement of Work}

The major project objective was to demonstrate utility repowering with a two-stage, pressurized, oxygen-blown, entrained-flow IGCC system, including advancements in the technology relevant to the use of high-sulfur bituminous coal, and to assess long-term reliability, availability, and maintainability at a commercial scale. Another goal was to evaluate the performance of all major process components, including the coal slurry feed system, the gasifier, the gas cleanup system, the modified combustion turbine utilizing medium-Btu gas, and the repowered steam turbine.

The Cooperative Agreement puts this in slightly different words, stating that the objective of this project was "to demonstrate an advanced coal gasification combined-cycle (CGCC) system based on Destec Energy, Inc.'s two-stage entrained flow gasification technology. The CGCC system will utilize high-sulfur bituminous coal, not to exceed 5.9 percent sulfur (dry basis), to produce high efficiency, cost competitive, and environmentally compliant electric power. The CGCC 
system will also provide data on the performance of all major subsystems, including coal slurry feed system, oxygen-blown two-stage entrained-flow coal gasifier, coal gas cleanup system, modifications to an advanced combustion turbine to utilize medium-Btu coal gas as fuel, and the repowered steam turbine to provide a combined-cycle system." The project had the following specific technology demonstration goals:

- Use integrated coal gasification combined-cycle technology to repower a 1950s-vintage coalfired power-generating unit.

- Achieve high energy efficiency and superior environmental performance while using highsulfur bituminous coal.

- Operate an IGCC facility in a utility electrical grid.

- Apply hot/dry-particulate removal at full commercial scale.

- Use syngas recycle to provide fuel and process flexibility, while maintaining high efficiency.

- Demonstrate high-pressure cooling of hot, raw syngas by producing 1,600 psia steam.

- Use a dedicated oxygen plant producing 95-percent oxygen to increase overall project efficiency by decreasing the power required for production of oxygen.

- Integrate the gasification facility with a heat-recovery steam generator to optimize both efficiency and operating costs.

- Apply a carbonyl-sulfide hydrolysis system to achieve high sulfur removal.

- Demonstrate operation of the slag-fines recycle system, which enhances carbon conversion and results in higher quality by-product slag by recycling the slag by-product stream to the gasifier.

- Demonstrate fuel-gas moisturization, which uses low-level heat to reduce steam injection required for $\mathrm{NO}_{\mathrm{X}}$ control.

- Demonstrate sour-water treatment and tail-gas recycling to increase efficiency and reduce waste water and emissions.

- Utilize an advanced gas turbine design to allow for the combustion of syngas and higher firing temperature configurations.

- Utilize saturated steam from the gasification-facility HRU to operate a steam turbine.

- Repower the existing steam turbine by upgrading the unit to accept increased steam flows generated by the HRSG. 
The Statement of Work (SOW) is broken down into three phases: Phase I—Design and Permitting; Phase II—Construction, Installation, and Startup; and Phase III-Operation, Data Collection, Evaluation, and Disposition. This PPA is primarily concerned with Phase III and does not deal with the other phases in any detail. Phase III included operation and demonstration of the installed system. The main area of interest was to assess the performance of the E-Gas ${ }^{\mathrm{TM}}$ Gasifier, but other systems, such as gas cleanup, heat recovery, and power generation were also critical to the success of the project.

The SOW stated that the Participant was responsible for the operation, modification, maintenance, data collection, and evaluation of the plant. In addition, performance and environmental data that establish the operational characteristics of the overall plant and major subsystems were to be collected and provided to DOE. The Participant was also responsible for providing all required reports.

The SOW specifies a 3-year demonstration period "during which Participant will implement plans and programs to operate, maintain, monitor, evaluate, and improve both the subject technology and the plans and programs themselves." Key demonstration-period goals were to

- Incorporate the E-Gas ${ }^{\mathrm{TM}}$ Gasifier-based IGCC power plant into the PSI system as a reliable and effective element of its baseload-generation capability.

- Demonstrate the operability, effectiveness, and economic viability of this technology on a commercial scale and in a commercial utility environment.

- Optimize the effectiveness of the overall system and to otherwise advance the technology.

- Obtain the data base and experience base necessary to meet and advance the commercial markets for this technology.

The SOW summarized the following ten areas: (1) Specification for Acceptance Testing;

(2) Gasification Facility Operating Discipline Program; (3) Power Block Operating Discipline Program; (4) Gasification Facility Maintenance Plan and Program; (5) Power Block Maintenance Plan and Program; (6) Data Acquisition System; (7) Program Regarding Operating Characteristics; (8) Environmental Monitoring Plan; (9) Plan to Test Alternative Feedstocks; and (10) Plan for DOE Communications. The SOW did not specifically define any set of conditions under which the gasification plant would operate; it merely stated that the date for commencement of commercial operations would occur after the plant had operated for 100 consecutive hours at 80 percent of the production rate specified in the Gasification Services Agreement (GSA). There was also a requirement that the gasifier operate for 100 consecutive hours at 100 percent of the GSA specified production rate.

The SOW also set the Demonstration Coal as bituminous coal from the No. 6 Seam at Peabody's Hawthorn Mine. However, the Participant had the option to substitute an alternative feedstock for a maximum of 60 days, once per year during the 3-year demonstration period. The choice of the alternative feedstock was not specified, but was left up to the Participant. 


\section{Technical And Environmental Review}

\section{III.A Technical Results}

Within a short time after startup, both the gasification and combined-cycle plants successfully ran at capacity and within environmental parameters. However, numerous operating problems impacted plant performance the first year, resulting in an availability of only 22 percent. Frequent failure of the ceramic filter elements accounted for nearly 40 percent of the downtime. Another problem was the high chloride content in the syngas; this contributed to exchanger tube failures in the low-temperature heat-recovery area, COS hydrolysis catalyst degradation, and mechanical failure of the syngas recycle compressor. Significant downtime was required to remove ash deposits that created high system pressure drops in the gasifier downstream pipe spool and the high temperature heat-recovery unit (HTHRU). The slurry mixers experienced several failures, and the power block also contributed appreciable downtime.

The foregoing problems were either eliminated or significantly reduced by the end of the second operating year. In 1997, the facility availability was 44 percent, and by 1998 the availability had improved to 60 percent. During the third year of the demonstration period, a second Illinois No. 6 coal was fed to the facility, as well as a blend of the two coals.

Despite reliability issues during the first 2 years of operation, the actual performance of the plant, while feeding coal compared, favorably with design, as shown in Table 2.

Table 2. Performance Summary

\begin{tabular}{|l|c|c|}
\hline Performance Criterion & Design & Actual \\
\hline Syngas Capacity, Mbtu/h & 1,780 & $1,690(1,825$ max $)$ \\
\hline Combustion Turbine Capacity, MW & 192 & 192 \\
\hline Steam Turbine Capacity, MW & 105 & 96 \\
\hline Auxiliary Power, MW & 35.4 & 36 \\
\hline Net Power, MW & 262 & 252 \\
\hline Plant Heat Rate, Btu/kWh & 9,030 & 8,900 \\
\hline Syngas Heating Value, Btu/SCF (HHV) & 280 & $275-280$ \\
\hline Syngas Sulfur Content, ppmv & $<100$ & $<100$ \\
\hline Sulfur Removal Efficiency, \% & $>98$ & $>99$ \\
\hline SO $_{2}$ Emissions, lb/MBtu & $<0.2$ & $<0.1(0.03)$ \\
\hline
\end{tabular}


The plant demonstrated a maximum production capacity of 1,825 million Btu per hour (MBtu/h), but the combustion turbine only required $1,690 \mathrm{Mbtu} / \mathrm{h}$ (approximately 1.2 trillion $\mathrm{Btu} / \mathrm{month}$ ) or less, depending on ambient temperature, at full load. As shown in Table 2, the power output of the steam turbine fell short of the design value. This was caused by a reduction in throttle steam to the steam turbine, made necessary by increased steam consumption in the deaerator (the result of an error in the design of the feedwater heater). Modifications to the HRSG feedwater heater will be required to increase steam production and bring steam turbine output up to design. With this modification, the overall plant heat rate will drop to 8,650 Btu/kWh. The ASU did not meet the guaranteed power requirement specification, which accounts for the somewhat higher than design auxiliary power requirement.

The greatest monthly output achieved during the demonstration period was achieved in September 1999, when 1,204,573 MBtu of gas were produced. Several other months came close to this level, with over 1 trillion Btu of gas being produced during March, April, October, and November 1998. During the third quarter of 1999, 2,712,107 MBtu were produced. Key production statistics for the demonstration period are presented in Table 3.

Table 3. WRCGR Project Production Statistics

\begin{tabular}{|l|l|l|l|l|l|c|}
\hline $\begin{array}{l}\text { Time } \\
\text { Period }\end{array}$ & $\begin{array}{l}\text { Time } \\
\text { on Coal, } \\
\text { hours }\end{array}$ & $\begin{array}{l}\text { Coal } \\
\text { Processed, } \\
\text { tons }\end{array}$ & $\begin{array}{l}\text { Gas } \\
\text { Produced, } \\
\text { MBtu }\end{array}$ & $\begin{array}{l}\text { Steam } \\
\text { Produced, } \\
\mathbf{1 0} \text { lb }\end{array}$ & $\begin{array}{l}\text { Power } \\
\text { Produced, } \\
\text { MWh }\end{array}$ & $\begin{array}{l}\text { Sulfur } \\
\text { Produced, } \\
\text { tons }\end{array}$ \\
\hline 1995 & 505 & $\sim 41,000$ & 230,784 & 171,613 & $\sim 71,000$ & 559 \\
\hline 1996 & 1,902 & 184,382 & $2,769,685$ & 820,624 & 449,919 & 3,299 \\
\hline 1997 & 3,885 & 392,822 & $6,232,545$ & $1,720,229$ & $1,086,877$ & 8,521 \\
\hline 1998 & 5,279 & 561,495 & $8,844,902$ & $2,190,393$ & $1,513,629$ & 12,452 \\
\hline $1999 *$ & 3,496 & 369,862 & $5,813,151$ & $1,480,908$ & $1,003,853$ & 8,557 \\
\hline Overall & 15,067 & $1,549,561$ & $23,891,067$ & $6,383,767$ & $4,125,278$ & 33,388 \\
\hline
\end{tabular}

* Combustion turbine unavailable from March 14, 1999 through June 22, 1999. Production in 1999 would have been the same as in 1998, if the combustion turbine had not been out of service for 3 months. Performance of various parts of the system are discussed in the following sections.

\section{III.A.1 Air-Separation Unit}

Although oxygen production is a well proven technology and the ASU should have achieved a high level of performance and availability, a number of problems were encountered with this unit. Early in 1996, the ASU was modified to provide additional nitrogen gas for equipment purging and other uses. Although these modifications were successful in increasing nitrogen production, the ASU never achieved the full performance guarantees for simultaneous delivery of all product streams. Because of the frequent plant interruptions in the early years, the supply of nitrogen was still inadequate and had to be supplemented by outside purchases, which increased operating costs. Through a series of process improvements and operating changes, nitrogen usage 
was significantly decreased from a 1997 high of 15 trucks per month $\left(9 \times 10^{6} \mathrm{ft}^{3}\right)$ down to two trucks per month $\left(1.2 \times 10^{6} \mathrm{ft}^{3}\right)$.

Oxygen production during 1997 was sufficient to meet the demands of the gasifier. Total annual production was approximately 328,000 tons of 95 -percent purity oxygen. Since there is no oxygen storage capability at the facility, a malfunction of the main air compressor caused a shutdown of the gasification process caused by the inability to supply oxygen to the slurry mixers. In 1998, oxygen production increased to over 442,000 tons. A number of plant improvements were implemented to increase ASU availability.

\section{III.A.2 Coal Handling}

In separate tests, two different coals, plus a blend of the two, and petroleum coke were fed to the gasifier during the demonstration period. The average properties of these fuels are shown in Table 4.

Table 4. Fuel Properties

\begin{tabular}{|l|l|l|l|l|}
\hline Fuel & $\begin{array}{l}\text { Hawthorn } \\
\text { Coal }\end{array}$ & $\begin{array}{l}\text { Miller } \\
\text { Creek } \\
\text { Coal }\end{array}$ & $\begin{array}{l}\text { Hawthorn/ } \\
\text { Miller } \\
\text { Creek Blend }\end{array}$ & $\begin{array}{l}\text { Petroleum } \\
\text { Coke }\end{array}$ \\
\hline Ultimate Analysis, wt\% (dry) \\
\hline Carbon & 69.98 & 71.36 & 69.66 & 87.49 \\
\hline Hydrogen & 4.65 & 4.69 & 4.85 & 2.74 \\
\hline Nitrogen & 1.28 & 1.38 & 1.44 & 0.99 \\
\hline Oxygen & 8.18 & 7.05 & 8.48 & 3.09 \\
\hline Sulfur & 2.61 & 3.45 & 2.95 & 5.17 \\
\hline Ash & 13.30 & 12.07 & 12.62 & 0.52 \\
\hline Water, wt\% as received & 14.60 & 16.50 & 15.30 & 7.00 \\
\hline Heating Value, Btu/lb (HHV) & 10,730 & 10,765 & 10,645 & 14,282 \\
\hline As Received & 12,567 & 12,890 & 12,566 & 15,353 \\
\hline Dry
\end{tabular}

The gasifier is capable of handling feedstocks with a relatively wide range of characteristics; however, variations too far from the design-basis coal could reduce syngas and steam production. Also, if undetected, sudden changes in feedstock composition can cause problems; therefore, feedstock analyses were followed closely. When petroleum coke was gasified, coal slag was added as a fluxing agent.

A rod mill is used, rather than a hammer mill, because in the E-Gas ${ }^{\mathrm{TM}}$ Gasifier, the fuel is fed as an aqueous slurry. Initially, the rod mill did not produce a fine enough grind, but this was corrected by adjusting the rod loading in the mill. Also, a number of areas of localized erosion and corrosion were identified throughout the slurry handling system. Where possible, hardened metal internal coatings were applied, while in some cases metallurgy had to be changed to 
improve equipment life. Another problem was foreign objects in the coal, which led to poor performance of the rod mill, resulting in downstream problems. This situation was resolved by improved quality control of the feed coal by the coal providers, and by the addition of magnetic separators on the belt feeder to remove tramp iron.

\section{III.A.3 Gasification}

At startup, the gasifier and downstream equipment were heated by natural-gas burners. During the transition to coal operation, both coal and natural gas were fed to the gasifier. Because of its low pressure and low flow rate, syngas generated during heat-up operations was not suitable for fueling the combustion turbine. Natural gas was also fired in the gasifier during standby operations. Natural gas was not fired in the combustion turbine. The number of hours on natural gas and on coal are shown in Table 5. Time on natural gas includes the total hours required to heat the gasifier and associated equipment, the transition time to full coal operation, and hot standby time. During the period from 1996 through 1998, there was a continual improvement in operations.

Table 5. E-Gas ${ }^{\mathrm{TM}}$ Gasifier On-Stream Hours

\begin{tabular}{|l|c|c|c|c|}
\hline Year & $\mathbf{1 9 9 6}$ & $\mathbf{1 9 9 7}$ & $\mathbf{1 9 9 8}$ & $\mathbf{1 9 9 9}$ \\
\hline Time on Natural Gas, hours & 1,990 & 1,490 & 976 & 933 \\
\hline Time on Coal, hours & 1,902 & 3,885 & 5,278 & 3,496 \\
\hline
\end{tabular}

Problems associated with gasifier operations included ash deposition in various locations and erosion of the brick lining. These problems were largely overcome by piping and operating procedure changes and by using a different refractory brick to line the gasifier. Problems with the slurry mixers.were improved by operational changes and installation of redesigned mixers. Problems were also encountered with taphole plugging, which can occur when a coal with varying ash viscosity is gasified without adding appropriate operating-temperature adjustments.

\section{III.A.4 Syngas Cooling and Particulate Removal}

Ash deposition in the HTHRU and associated equipment was of great concern during early operations. Thermal cycling in the hot-gas path was a leading cause of plugging which occurs because of spalling (flaking off) of ash deposits in upstream equipment and piping. Solids accumulation at the tubesheet caused tube plugging and high differential pressures. As plugging of some tubes occurred, the velocity of the solids-laden gas through the remaining open tubes became high enough to cause erosion. To help control ash deposition in the tubes of the HTHRU, a boiler inlet screen was installed to prevent large particles from reaching the tubesheet. Although fouling of the boiler tubes continued to be a concern that was not fully resolved, an improved mechanical tube-cleaning procedure and modified operating conditions reduced the problem to manageable proportions so that tube cleaning was required only every 6 months to a year. 
The particulate-removal system was initially a significant source of problems, but a considerable increase in performance occurred when the ceramic filter elements were replaced with metallic elements. Design improvements to provide better flow distribution through the filter vessels also helped.

\section{III.A.5 Chloride Scrubbing System and COS Hydrolysis}

The efficiency of the COS-hydrolysis unit decreased during the first 2 years because of catalyst poisoning by trace metals and chlorides and the loss of surface area caused by overheating. After replacement with a catalyst that was more poison resistant and installation of a chloride scrubbing system (CSS), the unit achieved a consistent COS concentration of $10 \mathrm{ppm}$ in the gas leaving the hydrolysis unit.

The CSS was installed to remove chlorides and other impurities from the syngas. Initially, some problems were observed caused by ammonia accumulation in the CSS, where hot syngas was scrubbed with sour water that absorbed both ammonia and chlorides. This resulted in sour water being sent to the sour-water receiver and then recycled back to the CSS. To avoid operational problems and provide an ammonia purge from the system, a blowdown stream was taken from the sour-water tank and sent directly to the sour-water system.

\section{III.A.6 Low-Temperature Heat Recovery and Syngas Humidification}

The syngas is humidified prior to being sent to the combustion turbine to control combustion temperature, reduce $\mathrm{NO}_{\mathrm{X}}$ formation, and improve efficiency. Syngas humidification operated efficiently and provided consistent product gas moisture content of approximately 20 to 23 percent throughout the demonstration period. Product syngas quality remained high (above 250 Btu/scf), as shown in Table 6.

Table 6. Product Syngas Composition

\begin{tabular}{|l|r|r|r|r|r|r|r|r|}
\hline Year & \multicolumn{2}{|c|}{1996} & \multicolumn{2}{c|}{1997} & \multicolumn{2}{c|}{1998} & \multicolumn{2}{c|}{1999} \\
\hline Concentration & Low & \multicolumn{1}{c|}{ High } & \multicolumn{1}{c|}{ Low } & \multicolumn{1}{l|}{ High } & \multicolumn{1}{c|}{ Low } & \multicolumn{1}{l|}{ High } & Low & High \\
\hline Hydrogen, \% & 32.87 & 34.21 & 32.90 & 34.40 & 32.71 & 33.82 & 32.31 & 33.44 \\
\hline Carbon Dioxide, \% & 14.89 & 17.13 & 16.60 & 16.90 & 14.92 & 16.06 & 15.25 & 16.22 \\
\hline Carbon Monoxide, \% & 42.34 & 46.03 & 42.20 & 46.70 & 44.25 & 46.73 & 44.44 & 46.31 \\
\hline Methane, \% & 1.26 & 1.99 & 1.04 & 2.02 & 1.91 & 2.29 & 1.88 & 2.17 \\
\hline Hydrogen Sulfide, ppmv & 17.28 & 83.36 & 43.08 & 106.50 & 23.48 & 107.2 & 86.32 & 106.0 \\
\hline Carbonyl Sulfide, ppmv & 36.26 & 162.13 & 22.59 & 111.80 & 9.03 & 36.63 & 11.36 & 24.22 \\
\hline $\begin{array}{l}\text { Heat of Combustion, } \\
\text { Btu/scf (HHV) }\end{array}$ & 256 & 280 & 254 & 283 & 268 & 284 & 267 & 280 \\
\hline
\end{tabular}


Syngas composition remained relatively constant during the demonstration period, even though coal composition changed. As discussed above, once problems with the COS removal system were resolved, COS levels remained low.

The low-temperature heat-recovery unit (LTHRU) initially had a problem with chloride stress corrosion cracking of the stainless steel exchanger tubes, but replacement of the tubes with more corrosion resistant materials and addition of the CSS essentially eliminated this problem.

\section{III.A.7 Acid-Gas Removal, Sulfur Recovery, and Sour-Water Stripping}

The AGR system operated well for most of the demonstration period, with removal efficiency generally holding above 98 percent. The only significant drop in efficiency occurred during a short period, when problems were encountered with the MDEA reclaim unit, which removes heat-stable salts. A vacuum distillation to remove heat-stable salts was performed during the fourth quarter of 1997. The distillation effectively restored the $\mathrm{H}_{2} \mathrm{~S}$-removal efficiency of the amine solution. A number of process improvements were implemented during the demonstration period, which improved the operation and reliability of the reclaim unit and overall AGR system.

After some initial modifications, the SRU performed well. Generally, over 95 percent of the sulfur fed to the SRU was recovered as high-purity sulfur. The tail gas from the SRU was recycled to the gasifier to enhance overall sulfur recovery. Based on the sulfur in the feed to the gasifier, overall sulfur recovery was typically in the range of 97.5 to 98.5 percent.

Except for a few minor upsets, the sour-water stripping system operated very well. The volume of treated water sent to disposal was typically about $10,000 \mathrm{gal} / \mathrm{h}$.

\section{III.A.8 Power Block}

During the demonstration period, the power block produced a total of 4,125 GWh of electric power. In general, the power block operated well until the first quarter of 1999, when the compressor rotor failed. The compressor was replaced by a new upgrade unit from General Electric, which has operated successfully since its installation.

\section{III.A.9 Operations Feeding Petroleum Coke}

Petroleum coke is a by-product of the refining industry. In the refinery, heavy materials that cannot be distilled are frequently sent to a coking unit, where pyrolysis produces a light fraction that can be incorporated into the refinery's slate of standard products (gasoline, diesel, etc.). The material left behind, referred to as petroleum coke, has a low hydrogen/carbon ratio and may be high in sulfur, but it has a low ash content (Table 4). Petroleum coke typically has a low economic value and is sometimes just piled up at the refinery. As the world's crude oil supply becomes heavier (i.e., contains a larger fraction of high boiling components), the production of petroleum coke should increase, and it should become more attractive as a fuel. 
Because of the flexibility of IGCC technology, petroleum coke is an opportunity fuel for these systems. Petroleum coke's low ash content and high heating value make it an attractive fuel, and its low fuel price can be used to offset the higher capital cost of an IGCC unit. Other potential opportunity fuels include coal fines, sewage sludge, MSW, RDF, waste tires, etc. Most of these materials would be co-fired as a mixture with coal, or with coal being fired to the first stage and the opportunity fuel being fired to the second stage.

A test period operating with petroleum coke was conducted as part of the WRCGR Project. The purpose of this test was to utilize petroleum coke as the primary feed, while operating in a typical power plant environment. Preparatory work included analysis of coke properties and ash characteristics, bench-scale reactivity testing, determination of grinding and slurrying characteristics, computer simulations of process and thermal performance, an industrial hygiene review, and development of coke/flux blending equipment.

About 18,000 tons of sponge coke from a delayed coker were processed from November 17 to November 27, 1997. The plant switched from coal to 100-percent, as-received, petroleum coke without interrupting operations. The coke had a sulfur content of 5 percent, which is well within the sulfur design limit of the Wabash River plant. Laboratory ash composition and ash fusion analyses indicated that slag from petroleum coke would be difficult to remove at typical gasifier operating temperatures. Therefore, prior to slurry preparation, slag from an earlier coal run, with known ash flow characteristics, was added to the feed as a fluxing agent. In the gasifier, trace metals in the petroleum coke, mainly vanadium and nickel, are encapsulated in the slag that is inert, non-leachable, and safe for non-hazardous disposal or use. Properties of the coke compared to a typical coal are shown in Table 7.

Table 7. Typical Fuel Analyses

\begin{tabular}{|c|c|c|}
\hline Property & Typical Coal & Petroleum Coke \\
\hline Proximate Analysis & 15.2 & 7.0 \\
\hline Moisture, \% & 12.0 & 0.3 \\
\hline Ash, \% & 32.9 & 12.4 \\
\hline Volatiles, \% & 39.9 & 80.3 \\
\hline Fixed Carbon, \% & 1.9 & 5.2 \\
\hline Sulfur, \% & Trace & 11.8 \\
\hline Metals in Ash & Trace & 28.4 \\
\hline $\mathrm{NiO}, \%$ of ash & 10,536 & 14,282 \\
\hline $\mathrm{V}_{2} \mathrm{O}_{5}, \%$ of ash
\end{tabular}


Operations were generally steady during the period feeding petroleum coke, although the plant shut down twice for brief periods, once because of a problem with the slurry feed pump and once caused by a problem with the dry char particulate filtration system. Neither was related to the change in feed. Operation at full load was achieved with 100-percent petroleum coke while meeting all environmental emissions criteria. For most of the test, operation was maintained at approximately 90 percent of gasifier capacity to match the combustion turbine fuel requirement, which was somewhat lower than that guaranteed by the turbine manufacturer. Overall plant efficiency at 40.2 percent (HHV) was slightly improved during petroleum coke operations (Table 8).

Table 8. Thermal Performance Summary for Operations With Petroleum Coke

\begin{tabular}{|l|c|c|c|}
\hline Performance Criteria & Design Coal & Actual Coal & Petroleum Coke \\
\hline Nominal Throughput, ton/day & 2550 & 2450 & 2000 \\
\hline Syngas Production, Mbtu/h & 1780 & 1690 & 1690 \\
\hline Combustion Turbine, MWe & 192 & 192 & 192 \\
\hline Steam Turbine, MWe & 105 & 96 & 96 \\
\hline Auxiliary Power, MWe & 35 & 36 & 36 \\
\hline Net Generation, MWe & 262 & 252 & 252 \\
\hline Plant Efficiency, \% (HHV) & 37.8 & 39.7 & 40.2 \\
\hline Sulfur Removal Efficiency, \% & $>98$ & $>99$ & $>99$ \\
\hline
\end{tabular}

No problems were encountered in grinding the petroleum coke. Slurry with a solids content of approximately 66 percent and good flow characteristics for pumping was consistently produced. Additional rods were added to the rod mill midway through the test to further reduce the particle size of the slurry, but this had no significant effect on the solids content.

Laboratory tests prior to on-line operation indicated that the petroleum coke would be much less reactive than coal. Initially, an average carbon conversion of about 97.5 percent was achieved with petroleum coke; however, following the addition of the grinding rods, which reduced the particle size, overall carbon conversion improved to over 99 percent.

Based on laboratory ash fusion and high-temperature slag viscosity tests, flux addition in the range of 5 to 10 tons of slag per 100 tons of petroleum coke was targeted for the test; but near the end of the test, to increase efficiency and reduce slag production, the flux ratio was reduced to about 2 tons/100 tons. No slag-tapping problems were encountered during the test.

Composition of the cleaned syngas was very similar to that produced when feeding bituminous coal, as shown in Table 9. 
Table 9. Product Syngas Composition

\begin{tabular}{|l|c|c|}
\hline Fuel & Typical Coal & Petroleum Coke \\
\hline Nitrogen, vol \% & 1.9 & 1.9 \\
\hline Argon, vol \% & 0.6 & 0.6 \\
\hline Carbon Dioxide, vol \% & 15.8 & 15.4 \\
\hline Carbon Monoxide, vol \% & 45.3 & 48.6 \\
\hline Hydrogen, vol \% & 34.4 & 33.2 \\
\hline Methane, vol \% & 1.9 & $0.5 *$ \\
\hline Total Sulfur, ppmv & 68 & 69 \\
\hline Heating Value, Btu/scf $(\mathrm{HHV})$ & 277 & 268 \\
\hline
\end{tabular}

* Because of limited data on petroleum coke, this value needs further verification.

The ash from the petroleum coke contained about 12-percent $\mathrm{NiO}$ and 28-percent $\mathrm{V}_{2} \mathrm{O}_{5}$. $\mathrm{Nickel}$ and vanadium are often of great concern in utility boiler operations. Vanadium-pentoxide has been found to aggressively attack boiler tubes. Process samples from solid, liquid, and gas streams were taken at various points in order to quantify trace metal contents. About 80 percent of the nickel and 99 percent of the vanadium were captured in the silicate matrix of the slag and rendered inactive in an inert, non-leaching solid, as confirmed by a Toxicity Characteristic Leaching Procedure (TCLP) environmental leachate test. Some nickel was found in ash deposits. Liquid and gas streams contained less than $1 \mathrm{ppm}$ nickel and vanadium. Trace metals should not be a problem when feeding petroleum coke.

The refractory wear rate, even at the elevated temperatures required for petroleum coke operations, was similar to that observed when feeding coal. No adverse impact on the metallurgy of the equipment was observed. Analysis of test coupons placed throughout the system indicated that corrosion was not much different than with coal. In particular, the metallic filters showed approximately the same corrosion rates as with coal. Ash deposition at the boiler inlet was slightly higher than normal, especially when temperatures in the second stage were increased. No additional deposits were noted in other areas.

Because of the lower reactivity of the petroleum coke, char loading to the dry char particulate removal filters was higher than with coal, but no filtration problems caused by the higher solids loading were observed. Sampling of the syngas at the gasifier outlet showed negligible amounts of tar.

As expected, both $\mathrm{H}_{2} \mathrm{~S}$ and $\mathrm{COS}$ levels in the raw syngas were much higher during the petroleum coke test; however, total sulfur in the product syngas was maintained at a level similar to that for coal operations. No problems were encountered with sulfur removal or recovery; the COS catalyst performed well, and no adverse impact on the catalyst was detected. 
The overall conclusion from the petroleum coke test is that operations with petroleum coke are not significantly different than operations with coal and that the equipment and systems at Wabash River are adequate for this operation without modification.

\section{III.B Environmental Performance}

The WRCGR Project was designed to demonstrate that retrofitting a coal gasification/combustion turbine system to an existing electrical generating unit could, while feeding a high-sulfur (up to 5.9 percent) coal, achieve pollutant emissions levels commensurate with current and upcoming environmental regulations, especially those contained in the Clean Air Act Amendments of 1990 (CAAA). The project also included environmental compliance with the air and water pollution requirements specified in the Indiana Department of Environmental Management's (IDEM) Title V Operating Permits Program.

IGCC plants use gasifiers to convert various carbon-based feedstocks to syngas (a mixture of $\mathrm{H}_{2}$ and $\mathrm{CO}$ ). The hot syngas is cooled and cleaned of particulates, sulfur, and other contaminants by technologies that are commonly used in natural-gas purification and oil refining. As a result, atmospheric emissions of pollutants are very low. The syngas is combusted in a high-efficiency gas turbine/generator unit. Heat from the exhaust gas is extracted to produce steam to drive a steam turbine. Because IGCC plants operate at higher efficiencies, and because pollutants are readily removed from the syngas, these systems emit less pollution per unit of energy than conventional fossil-energy fueled power plants.

By repowering a 1950s-vintage coal-fired boiler/steam turbine unit with an advanced gasification system, WRCGR Project personnel were able to economically and efficiently reduce environmental pollution. The operation of this full-scale CCT demonstration project did not, in general, increase the volume or composition of plant emissions, but rather significantly reduced pollutant levels, including sulfur dioxide $\left(\mathrm{SO}_{2}\right), \mathrm{NO}_{\mathrm{X}}$, particulates, $\mathrm{CO}_{2}$, and air toxics compared to baseline emissions before refurbishment. Average emissions were $0.1 \mathrm{lb} / \mathrm{MBtu}$ for $\mathrm{SO}_{2}$, which is less than one-tenth of the permitted limits. Emission rates as low as $0.03 \mathrm{lb} / \mathrm{MBtu}$ have been achieved. $\mathrm{NO}_{\mathrm{X}}$ emissions are $0.15 \mathrm{lb} / \mathrm{MBtu}$, which meets the target for 2003 specified under Title I of the CAAA. Particulate emissions were less than the detectable limit. $\mathrm{CO}$ emissions, at 0.40 $\mathrm{lb} / \mathrm{MBtu}$, were half that of the pre-repowering emission rate, and well below permitted limits.

For $\mathrm{SO}_{2}$, the New Source Performance Standards (NSPS) for fossil-fuel-fired electric generating units call for $1.2 \mathrm{lb} / \mathrm{MBtu}$ of heat input and 90-percent reduction from the uncontrolled emissions rate. The $\mathrm{SO}_{2}$ emissions rate for Wabash River of $0.1 \mathrm{lb} / \mathrm{MBtu}$ represents a reduction of 97 percent; therefore, both criteria were met. For $\mathrm{NO}_{\mathrm{X}}$, the NSPS has been revised to an outputbased regulation, at $1.6 \mathrm{lb} / \mathrm{MWh}$ of electric power generated. The Wabash River emissions figure of $1.09 \mathrm{lb} / \mathrm{MWh}$ meets this criterion. For particulate matter, the NSPS is $0.03 \mathrm{lb} / \mathrm{MBtu}$. With particulate emissions below the detectable limit, Wabash River meets this requirement. $\mathrm{CO}_{2}$ emissions were reduced by approximately 20 percent on a per $\mathrm{kWh}$ basis. The facility also reduced waste by producing two useful by-products, high-purity sulfur and non-hazardous slag, 
which could be marketed to commercial and industrial users. Recycling water for reuse further emphasized the positive environmental characteristics of the project.

The only environmental problem encountered related to water quality. Results showed that condensation of arsenic, selenium, and cyanide from the syngas vapor stream created elevated levels of these materials in the process wastewater, causing the plant to be out of permit compliance. The project is under an Administrative Order from IDEM to achieve compliance by September 2001. Investigations are underway to mitigate this problem by identifying the most cost-effective, currently available technologies. Approaches under consideration include chemical precipitation, bio-remediation, reverse osmosis, and evaporation. The additional cost and complexity of these potential solutions should be factored into any planned replication of this CCT coal gasification repowering technology. 


\section{Market Analysis}

\section{IV.A Market Size/Commercialization}

The total of all gasification projects, including those projected to start up by 2004, is a little over 30,000 equivalent megawatts, according to the 1999 World Gasification Survey. This survey is a database of all the gasification projects in the world on all fuels (natural gas, coal, petroleum coke, biomass) and producing all products (power, hydrogen, heat, and chemicals). Of the installed capacity, a little more than half (approximately 54 percent) is coal- or petroleum cokebased. The survey shows that there has been a significant increase in gasification activity in the past decade. In particular, the majority of the recent increase in installed gasification capacity is fueled by coal or petroleum coke. Of the 16,500 MW of solid fueled capacity, nearly half (43 percent) has started up, or is starting up, in the 10-year period ending in 2004 (Figure 10).

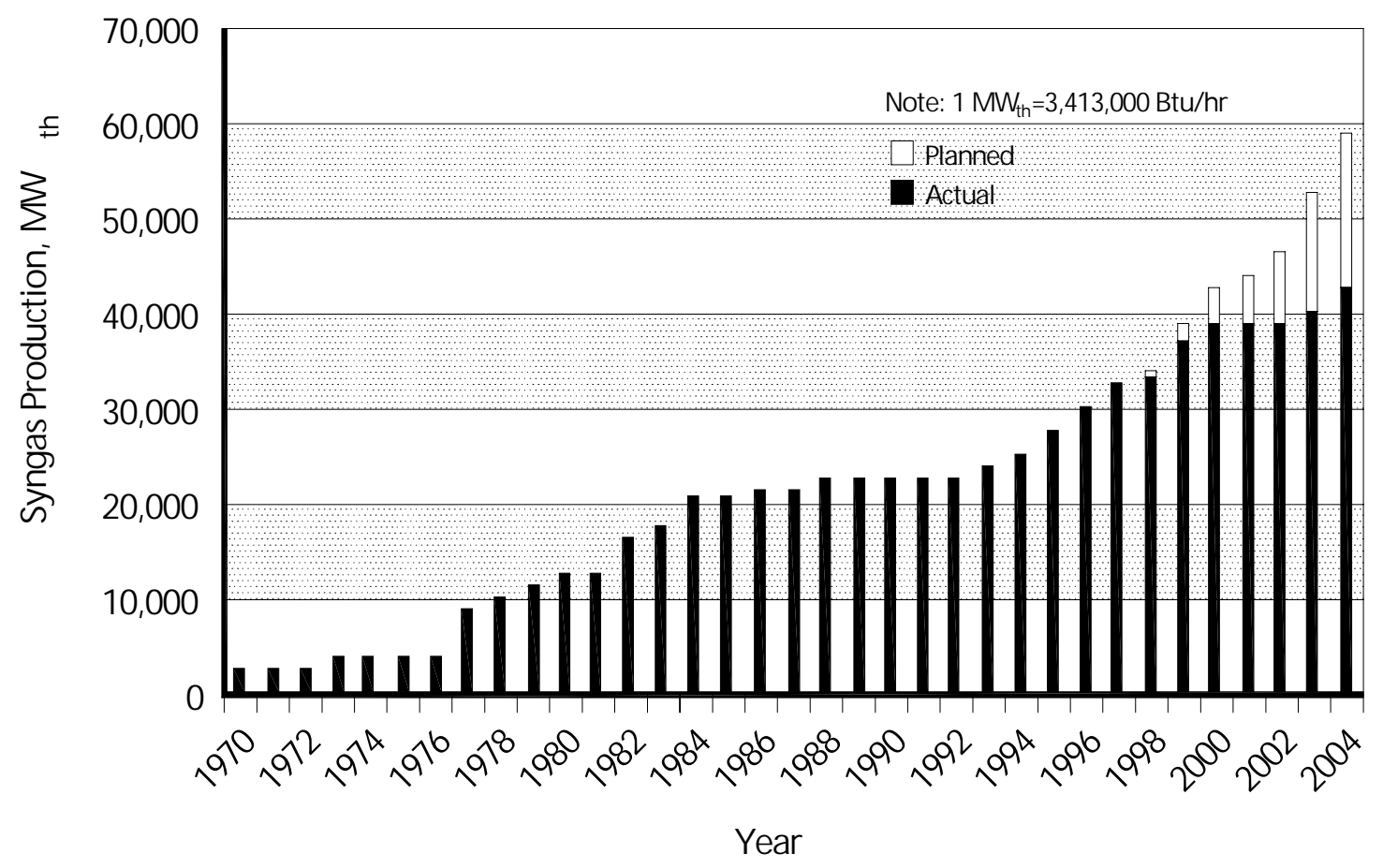

Figure 10. Worldwide Gasification Capacity

One impetus for this growth is the increased costs for environmental compliance with conventional PC-fired units, the drive to improve efficiencies, the availability of low-cost alternative feedstocks, and the need to utilize indigenous coal in areas without access to natural gas. The maturation of gasification technologies through completion of several large-scale demonstration projects has made this technology a popular and viable alternative to conventional combustion technologies 
In addition to generating power, the IGCC process can also be modified to produce value-added chemicals or transportation fuels from coal by chemical processing of the gas produced, as opposed to using the gas to drive a combustion turbine. It may be that the near-term market niche for IGCC lies not only in the production of electricity, but also in the generation of multiple products, where electricity, steam, and chemicals are economically bundled as products from a fully integrated complex.

General Electric Company (GE) reported (Todd 1998) that about 5,000 MW of gasification projects for power generation have proceeded to the point of placing orders for combustion turbines. Many of these projects include coproduction facilities for production of hydrogen and/or chemicals. GE is also in discussions with various refiners, developers, and others about projects totaling another 50,000 MW. This indicates a significant market for gasification technology in the near future, bolstered by trends of rising energy prices and tightening environmental controls. The E-Gas ${ }^{\mathrm{TM}}$ Technology, caused by its successful demonstration in the WRCGR Project, should be in a good position to capture a significant fraction of this market.

Indications are that many new domestic gasification projects will be refinery-based, utilizing petroleum coke and other low-cost refinery by-products to produce power, steam, hydrogen, and chemicals for the refinery and additional power for internal use or export. Global Energy has prepared the E-Gas ${ }^{\mathrm{TM}}$ Technology for these applications through a petroleum-coke operational test program at the Wabash River facility.

The E-Gas ${ }^{\mathrm{TM}}$ Technology is also being readied for coproduction applications through other studies and cooperative evaluation programs, some of which are taking place under DOE sponsored projects. Optimizing plant performance and improving the operating life of certain components of the plant is also being thoroughly investigated.

Global Energy expects that the E-Gas ${ }^{\mathrm{TM}}$ Technology, as demonstrated at the Wabash River facility on both coal and petroleum coke feedstocks, will be utilized in a significant portion of new solid fuel-based gasification facilities. Because of excellent environmental performance, the E-Gas ${ }^{\mathrm{TM}}$ Gasifier should be well suited to refinery-based applications utilizing petroleum coke in areas that are not in compliance with air emissions standards.

The potential market for repowering with the E-Gas ${ }^{\mathrm{TM}}$ Technology includes many existing utility boilers fueled by coal, oil, or natural gas. In addition to cost-effective reductions of $\mathrm{SO}_{2}$ and $\mathrm{NO}_{\mathrm{X}}$ emissions attainable by using gasification technology, net plant heat rate is improved as a direct result of the combined-cycle feature of the technology, which integrates a combustion topping cycle with a steam bottoming cycle. This technology is suitable for repowering applications and can be applied to any existing steam cycle located at plants with enough land area to accommodate coal handling and storage, and gasification and power facilities.

Somewhat further in the future, as the price of other forms of energy (particularly natural gas) increases domestically, and as existing conventional coal-fired power-generating stations strive to meet future environmental regulations, a market should develop in the United States for 
repowering 1960s- and 1970s-vintage coal plants and natural gas-fired combined-cycle plants. The E-Gas ${ }^{\mathrm{TM}}$ Technology should be well positioned for these applications.

\section{IV.B Economics}

\section{IV.B.1 Capital Costs}

Based on a study by Nexant LLC, the estimated capital cost of a 262-MWe power plant built on a greenfield site and incorporating all the information learned from operation of the Wabash facility would be $\$ 1,275 / \mathrm{kW}$ ( in 2000 dollars). Heat rate for this facility would be 8,250 $\mathrm{Btu} / \mathrm{kWh}(\mathrm{HHV})$. If petroleum coke was used instead of coal, the estimated capital cost would drop to $\$ 1,150 / \mathrm{kW}$. These estimates are shown in Table 10 .

Table 10. E-Gas ${ }^{\mathrm{TM}}$-Based IGCC Capital Costs

\begin{tabular}{|c|c|c|}
\hline Fuel & Coal & Petroleum Coke \\
\hline Capital Investment, $\$ / \mathrm{kW}$ & & \\
\hline Gasifier & 560 & 435 \\
\hline ASU & 140 & 140 \\
\hline Power Block & 575 & 575 \\
\hline Total & 1,275 & 1,150 \\
\hline
\end{tabular}

\section{IV.B.2 Operating Costs}

As stated above, the estimated heat rate for the plant is $8,250 \mathrm{Btu} / \mathrm{kWh}$. If the facility feeds medium-to-high-sulfur Midwestern coal at $\$ 1.25 / \mathrm{MBtu}$, then the fuel cost per $\mathrm{kWh}$ is 10.3 mills. The Final Report (Dowd 2000) estimates the yearly non-fuel operating costs at 5.2 percent of installed capital costs. Thus, for an installed capital cost of $\$ 1,275 / \mathrm{kW}$, non-fuel operating costs would be $10 \mathrm{mills} / \mathrm{kWh}$ at a 75 -percent operating factor.

\section{IV.B.3 Cost of Electricity}

The basis for the economics of the E-Gas ${ }^{\mathrm{TM}}$ Technology-based, combined-cycle, power-plant project are given in Table 11.

The cost of electricity using these parametric values is given in Table 12 on both a current-dollar and constant-dollar basis. The levelized costs are considerably reduced when feeding petroleum coke instead of coal, because the higher heating value and reduced ash will decrease solids handling and maintenance costs. Also, fuel costs are much lower, since petroleum coke may be only 15 to 25 percent the cost of coal. 
Table 11. Basis for Economic Evaluations

\begin{tabular}{|l|c|c|}
\hline Economic Parameter & Coal & Petroleum Coke \\
\hline Generating Capacity, MWe (net) & 270 & 271 \\
\hline Plant Heat Rate, Btu/kWh (HHV) & 8,910 & 8,790 \\
\hline Plant Capital Cost, \$/kW & 1275 & 1,150 \\
\hline Plant Operating Cost, \% of capital & 5.2 & 4.5 \\
\hline Capacity Factor, \% & 75 & 80 \\
\hline Fuel Cost, \$/ton & 20 & 5 \\
\hline Fuel Heating Value, Btu/lb & 10,500 & 14,500 \\
\hline
\end{tabular}

Table 12. Economics* of Power Generation by an IGCC Unit Using E-Gas ${ }^{\mathrm{TM}}$ Technology

\begin{tabular}{|c|c|c|c|c|c|}
\hline \multirow[t]{2}{*}{ Coal } & \multirow[t]{2}{*}{ Base, $\$ 10^{6}$} & \multicolumn{2}{|c|}{ Current Dollars } & \multicolumn{2}{|c|}{ Constant Dollars } \\
\hline & & Factor & Mills/kWh & Factor & Mills/kWh \\
\hline Capital Charge & 344.3 & 0.160 & 31.05 & 0.124 & 24.06 \\
\hline Fixed O\&M Cost & 17.9 & 1.314 & 13.26 & 1.000 & 10.09 \\
\hline Variable Operating Cost & 13.9 & 1.314 & 10.27 & 1.000 & 7.81 \\
\hline Levelized Cost of Power & & & 54.58 & & 41.96 \\
\hline \multicolumn{6}{|l|}{ Petroleum Coke } \\
\hline Capital Charge & 311.7 & 0.160 & 26.26 & 0.124 & 20.35 \\
\hline Fixed O\&M Cost & 14.0 & 1.314 & 9.70 & 1.000 & 7.38 \\
\hline Variable Operating Cost & 2.9 & 1.314 & 1.99 & 1.000 & 1.52 \\
\hline Levelized Cost of Power & & & 37.95 & & 29.25 \\
\hline
\end{tabular}

* Estimation based on information from Participant's Final Report. 


\section{Conclusions}

The WRCGR Project successfully demonstrated that the E-Gas ${ }^{\mathrm{TM}}$ Technology can be operated for extended periods of time and produce syngas of sufficient heating value to be burned in a combustion turbine for the production of electricity. All the technical goals were met. Although the E-Gas ${ }^{\mathrm{TM}}$ Technology has been demonstrated and used to repower an existing PC-fired boiler, at the completion of the Demonstration Project in December 1999, there were some areas where additional improvements were desirable to increase availability and reduce operating costs such as improving slurry-mixer reliability and decreasing trace compound concentrations in the wastewater. Although the particulate-removal system was not a significant problem at the end of the Demonstration, improved candle filters would be desirable. Also, coal ash composition must be carefully monitored so that changes in the feed coal do not lead to tap hole plugging. Because the E-Gas ${ }^{\mathrm{TM}}$ gasifier has continued to operate since the completion of the Demonstration Project, additional information on performance may be available from Global Energy, the current owner of the technology.

When coupled with well-designed auxiliary units, the E-Gas ${ }^{\mathrm{TM}}$ Technology emits very low levels of pollution. This is because nitrogen in the fuel leaves the gasifier as ammonia, and sulfur in the fuel leaves the gasifier as hydrogen sulfide. Ammonia is easily scrubbed from the syngas using a water wash, and can be recovered for sale or converted to nitrogen gas and water. Thus, fuel $\mathrm{NO}_{\mathrm{X}}$ production is negligible. Furthermore, combustion temperatures in the combustion turbine are lower than in typical PC-fired boilers, so that thermal $\mathrm{NO}_{\mathrm{X}}$ production is also lower. $\mathrm{The}_{2} \mathrm{H}_{2} \mathrm{~S}$ in the syngas is easily removed using any of a number of commercially available acid-gas removal processes. The recovered $\mathrm{H}_{2} \mathrm{~S}$ can then be converted to very pure sulfur for sale. This is a much more efficient procedure than trying to scrub $\mathrm{SO}_{2}$ from flue gas, and also avoids the problem of disposing of large quantities of scrubber sludge.

The gasifier was operated successfully on both bituminous coal and on petroleum coke, thus demonstrating its ability to handle a wide range of feeds. The potential exists to use a variety of fuels of opportunity, such as MSW, RDF, sewage sludge, waste tires, etc., either alone or, more likely, cofired with coal.

Interest in IGCC is continuing to grow because of its improved efficiency and reliability. The E-Gas ${ }^{\mathrm{TM}}$ Gasifier seems well positioned to supply a significant portion of this market. Future replication of the E-Gas ${ }^{\mathrm{TM}}$ Gasifier will furnish the marketplace with an efficient and environmentally benign technology capable of meeting today's strict environmental standards. The continued operation of the Wabash facility demonstrates the successful completion of this project. 


\section{Abbreviations}

AGR

Air Liquide

ASU

CAAA

CCT

CGCC

CO

$\mathrm{CO}_{2}$

COS

cold box

CSS

DOE

DE\&CS

GE

GSA

$\mathrm{H}_{2}$

HP

HHV

HRSG

$\mathrm{H}_{2} \mathrm{~S}$

HTHRU

IDEM

IP

IGCC

LGTI

LP

LTHRU

MDEA

MSW

$\mathrm{NH}_{3}$

$\mathrm{NO}_{\mathbf{X}}$

NSPS

PPA

PC

RDF

SOW

$\mathrm{SO}_{2}$

SRU

TCLP

WRCGR

WRCGRPJV acid-gas removal

Liquid Air Engineering Corporation

air-separation unit

Clean Air Act Amendments of 1990

Clean Coal Technology

coal gasification combined-cycle

carbon monoxide

carbon dioxide

carbonyl sulfide

cryogenic distillation system

chloride-scrubbing system

U.S. Department of Energy

Dow Engineering \& Construction Services

General Electric Company

Gasification Services Agreement

hydrogen

high-pressure

high heating value

heat-recovery steam generator

hydrogen sulfide

high-temperature heat-recovery unit

Indiana Department of Environmental Management

intermediate pressure

integrated gasification combined-cycle

Louisiana Gasification Technology, Inc.

low-pressure

low-temperature heat-recovery unit

methyldiethanolamine

municipal solid waste

ammonia

nitrogen oxides

New Source Performance Standards

post-project assessment

pulverized coal

refuse-derived fuel

Statement of Work

sulfur dioxide

sulfur-recovery unit

Toxicity Characteristic Leaching Procedure

Wabash River Coal Gasification Repowering

Wabash River Coal Gasification Repowering Project Joint Venture 


\section{References}

Dowd, Roy A. 2000. Wabash River Coal Gasification Repowering Project-Final Technical Report. Global Energy .

Todd, Doug. 1998. New Markets for CCT's. Paper presented at Sixth Clean Coal Technology Conference, April 28-May 1, Reno, Nevada.

U.S. Department of Energy. 1992. Comprehensive Report to Congress-Clean Coal Technology Demonstration Project-Wabash River Coal Gasification Repowering Project. DOE/FE-0257P. Springfield VA. National Technical Information Service. 


\section{Bibliography}

Amick, Phil. 2000.Commercial Operation of the Wabash River Coal Gasification Repowering Project. Paper presented at Electric Power 2000 conference, April, Cincinnati, Ohio.

Dowd, Roy A. 1996. Wabash River Coal Gasification Repowering Project-Annual Technology Report January-December 1996. Global Energy.

Dowd, Roy A. 1997. Wabash River Coal Gasification Repowering Project-Annual Technology Report January-December 1997. Global Energy.

Dowd, Roy A. 1998. Wabash River Coal Gasification Repowering Project-Annual Technology Report January-December 1998. Global Energy.

U. S. Department of Energy. 1996. The Wabash River Coal Gasification Repowering Project. Clean Coal Technology Topical Report Number 7. November.

U. S. Department of Energy 2000. The Wabash River Coal Gasification Repowering ProjectAn Update. Clean Coal Technology Topical Report Number 20. September. 